Luxembourg Income Study Working Paper No. 264

RETHINKING THE SOCIOLOGICAL

MEASUREMENT OF POVERTY

David Brady

revised August 2002 


\title{
RETHINKING THE SOCIOLOGICAL MEASUREMENT OF POVERTY*
}

\author{
David Brady \\ Duke University \\ Forthcoming in Social Forces
}

August 12, 2002

Word count: 12,079 (excluding Tables and Figure)

Running Head: Poverty Measurement

* Please direct correspondence to David Brady, Department of Sociology, Duke University, Box 90088, Durham, NC, 27708-0088, email: brady@soc.duke.edu. I appreciate helpful comments from two Social Forces reviewers, Art Alderson, Jason Beckfield, Clem Brooks, Katy Fallon, David Jesuit, Jane McLeod, Phil Morgan, Jason Schnittker, and especially Michael Wallace. This paper was presented at the 2001 American Sociological Association meetings in Anaheim, California. This paper received the Aldi J.M. Hagenaars Luxembourg Income Study Memorial Award, and the Karl Schuessler Award for Graduate Research Excellence at Indiana University. 


\section{RETHINKING THE SOCIOLOGICAL MEASUREMENT OF POVERTY* \\ ABSTRACT}

Despite serious methodological problems, quantitative studies of poverty by U.S. sociologists predominantly rely on the official U.S. measure. After reviewing the shortcomings of the U.S. measure, this paper examines several theoretical and methodological advances in poverty measurement. Synthesizing this literature, I argue that ideal measures of poverty should: a) measure comparative historical variation effectively; b) be relative rather than absolute; c) conceptualize poverty as social exclusion; d) assess the impact of taxes, transfers and state benefits; and e) integrate the depth of poverty and the inequality among the poor. Next, this paper evaluates sociological studies published since 1990 for their consideration of these criteria. Due to sociology's neglect of these criteria, this paper advocates for three alternative poverty indices: the Interval Measure, the Ordinal Measure, and the Sum of Ordinals Measure. Finally, with the Luxembourg Income Study, I examine the empirical patterns with these three measures, across advanced capitalist democracies from 1967 to 1997 . Estimates of these poverty indices are made available for future research. 


\section{RETHINKING THE SOCIOLOGICAL MEASUREMENT OF POVERTY*}

In the first few pages of his classic The Truly Disadvantaged, William Julius Wilson lamented the paucity of poverty scholarship by sociologists in the 1970s and early 1980s. Reacting, in part, to the climate surrounding Moynihan's (1965) studies of the Black family and Wilson's book The Declining Significance of Race, many scholars avoided the study of poverty during this period. Fortunately, Wilson's 1987 book triggered an enthusiastic resurgence in the study of poverty, and sociological research subsequently proliferated. Since 1990, in prominent and relevant sociological journals, 53 empirical, quantitative studies featured poverty as the dependent variable or as a key independent variable. Many other articles, and far more scholarly books, analyze poverty with a qualitative or theoretical approach. Sociologists have answered Wilson's call and poverty research has experienced a vibrant reinvigoration.

Sociology's revitalization of poverty research has produced significant empirical findings, theoretical contributions and policy applications. At the same time, several conventional methodological practices have become widely accepted. While these conventions demonstrate effective scientific replication, this consensus has simultaneously obscured one very crucial methodological concern. On the whole, the measurement of poverty has not received the scrutiny it deserves. Most sociologists of poverty rely on estimates of the official U.S. measure of poverty - presuming such statistics are both valid and reliable. In a few cases, sociologists modestly augment the U.S. measure with slight alterations or by supplementing it with other indicators. However, most archival quantitative data sets supply researchers with dichotomous variables identifying respondents as below or above the official level. Typically, scholars use these simple dummy variables and hope measurement issues are resolved. In turn, the vast majority of sociological studies of poverty utilize a seriously problematic measure of poverty. 
Despite these problems, sociologists' measurement of poverty would be somewhat acceptable if no feasible alternatives existed. To the contrary, however, a wealth of scholarship focuses on this very issue. Several social scientists have devoted their entire careers to devising innovative and useful techniques for the measurement of poverty. ${ }^{1}$ Though a few of these techniques are impractical and/or flawed, significant methodological and theoretical advances have been made. Despite the relevance of this research to the sociology of poverty and the popularity of this literature across the social sciences, sociologists have not sufficiently integrated these advances.

Of course, these alternatives would not warrant sociologists' attention, if different measures of poverty produced identical or even similar empirical conclusions and policy implications. However, this is far from the case. Hagenaars (1991: 134) explains that, "Both the population of poor and the extent of their poverty appear to depend to a large extent on the definition chosen.” Betson and Warlick (1998) convincingly demonstrate that the number, composition and trends in U.S. poverty significantly depend on the particular measure chosen. In fact, simply ascertaining whether poverty has increased in the last thirty years has dramatically different answers with contrasting measures of poverty (see Jorgenson 1998; Triest 1998). Thus, poverty measurement decisions have very real, substantive and policy consequences that potentially affect the scientific inferences of research (Hill and Michael 2001; Iceland et al. 2001).

Overall, this paper attempts to provide a guide for sociologists, while facilitating a stronger connection between sociology and the theoretical and methodological advances in the measurement of poverty. First, I revisit the shortcomings of the official U.S. poverty measure. Second, I discuss several emerging theoretical and methodological advances in the measurement 
of poverty, and advocate five criteria for the measurement of poverty: a) measure comparative historical variation effectively; b) be relative rather than absolute; c) conceptualize poverty as social exclusion; d) assess the impact of taxes, transfers and state benefits; and, e) integrate the depth of poverty and the inequality among the poor. Third, I evaluate sociological research since 1990 for its application of these criteria. Fourth, I advocate for three alternative indices that resolve the problems of sociological measures of poverty while adhering to these criteria: the Interval Measure, the Ordinal Measure, and the Sum of Ordinals Measure. Finally, with the Luxembourg Income Study (LIS), this paper empirically examines these indices across advanced capitalist democracies from 1967 to 1997.

\section{SHORTCOMINGS OF THE OFFICIAL U.S. MEASURE}

In recent years, many scholars, journalists and policy-makers have criticized the official U.S. measure of poverty (e.g. Ruggles 1990). Betson and Warlick (1998: 351) emphasize that the U.S. measure, "Is commonly acknowledged to be inadequate for measuring poverty." Wilson (1991: 3) argues that the U.S. measure, "Does not capture the real dimensions of hardship and deprivation, it also does not reflect the changing depth or severity of poverty." In turn, the Family Support Act of 1988 called for a scientific review of the U.S. measure. In 1995, the National Research Council (NRC), and specifically the Panel on Poverty and Family Assistance, published the results of this scientific review. The NRC panel (in its report edited by Citro and Michael 1995), which included many of America's most influential poverty researchers, broadly concluded that the U.S. measure is outdated and should not be retained. ${ }^{2}$

Mollie Orshansky (1965), head of the Social Security Administration under President Johnson, constructed the measure in 1963. Johnson reportedly sought a measure that was sufficiently conservative to render the eradication of poverty as an attainable goal of his "War on 
Poverty" (Betson and Warlick 1998; Katz 1989). Orshansky used family consumption data from 1955 (Wilson 1991) and what she called a "crude" calculus of family budgets. ${ }^{3}$ Though seemingly logical, Wilson (1991: 2) stresses that the U.S. measure "Represents arbitrary income thresholds" which have little relevance to contemporary American society. The dubious origins and significant elapsed time since the measure's inception, at a minimum, warrant regular review and updating. The NRC panel went one step further and argued, "Our major conclusion is that the current measure needs to be revised" (Citro and Michael 1995: 1). In turn, poverty analysts increasingly conclude that the antiquated official poverty line is no longer appropriate. ${ }^{4}$

Moreover, many analysts fault the U.S. measure's lack of reliability because it obscures differences in the extent of poverty among population groups and across geographic contexts, and provides an inaccurate picture of trends over time (Citro and Michael 1995; Haveman 1987). Because the measure remains unchanged after thirty years, significant demographic, economic, and policy changes are ignored (Blank 1997). Specifically, the NRC noted the increased labor force participation of mothers, the relatedly escalating need and expenses for child care and health insurance, differences in health status, and the inappropriateness of antiquated family size adjustments (Citro and Michael 1995; Betson and Warlick 1998). Lichter (1997) laments the unsophisticated equivalence scale (see below), which does not reliably measure poverty across family sizes and forms. Also, Ruggles (1990) explains that the relative share of family budgets devoted to different goods and services has changed. ${ }^{5}$ Foster (1998) adds that over time the U.S. measure has depreciated from its value in 1963 , and become unreflective of what a family really needs to avoid poverty. Because of rising consumption and living standards, the NRC (1995) concluded that updating the poverty threshold solely with inflation is increasingly inadequate. In 
short, the U.S. measure lacks reliability due in large part to the limited and weak means of adjusting the measure since its inception.

Similarly, many scholars (e.g. Slesnick 1993; Jorgenson 1998) argue that the U.S. measure lacks validity because it fails to capture the complex nature of poverty. Many increasingly burdensome family expenses (e.g. health and child care) are not encompassed in the U.S. measure. In addition, the measure ignores cash, near-income and in-kind public assistance, and taxes that effectively alter a family's disposable income (Lichter 1997; Citro and Michael 1995; Betson and Warlick 1998). Neglecting these government benefits, the U.S. measure violates the transfer axiom (Sen 1976, see below), fails to grasp the financial reality of poor families, and significantly underestimates the extent of poverty in the U.S. (Ruggles 1990). Because these validity problems have varied over time and place, reliability is also compromised. Taxes, such as the social security payroll tax, have varied across the U.S. and have increased enormously since the measure's inception (Lichter 1997; Betson and Warlick 1998). Moreover, future policy initiatives (e.g. the extension of Medicaid, and the Children's Health Insurance Plan) will not be captured by the measure (Citro and Michael 1995). In sum, the U.S. measure lacks both validity and reliability, and warrants revision.

Though the construction of a flawless measure is unlikely, the NRC and others suggest important revisions to improve poverty measurement. First, many scholars argue for a more significant temporal revision to the measure as living standards and consumption rise. Second, many analysts argue simply that the threshold should be raised to include those just above or near the poverty line. Third, a rising consensus argues for a reorientation towards a relative standard. While the U.S. measure purports to delineate a family's absolute level of minimum needs, the NRC recommended that the threshold be explicitly refocused on the relative 
consumption of contemporary U.S. families. With the NRC's proposed alternative measure, analysts have demonstrated significantly different historical trends in U.S. poverty (Triest 1998; Betson and Warlick 1998); much higher poverty rates (Hill and Michael 2001); smaller gaps between child and adult poverty rates (Iceland et al. 2001); and, importantly, different social consequences of child poverty (Hill and Michael 2001). ${ }^{6}$ Unfortunately, despite these scholars' efforts, the government has not implemented significant changes to its measure. While a lack of political will probably explains the inaction of the U.S. government, sociologists have no such justification. It is time that sociologists moved away from this flawed measure.

\section{MEASURING COMPARATIVE HISTORICAL VARIATION IN POVERTY}

For decades, sociologists have sustained interest in the comparative patterns and historical trends in poverty and inequality (e.g. Alderson and Nielsen 1999; Brady and Wallace 2001; Firebaugh 2000; Casper et al. 1994). Unfortunately, however, the discipline's reliance on the U.S. measure has limited our contribution to the understanding of these dynamics. For research on poverty to advance, measures must be developed to carefully gauge the comparative historical variation in poverty.

Many analysts document that the paramount variations in poverty are cross-national (e.g. Atkinson 1998a). Hence, explaining these significant cross-country differences is essential to understanding poverty in contemporary societies (Cantillion 1997). In addition, a comparative perspective provides leverage in assessing the influence of causal factors like economic change, public policy and demographic shifts. Given these benefits, several methodological concerns emerge when comparing poverty across nations. Several analysts note that different measures of poverty produce small but important differences in the rank ordering of nations (Atkinson 1998a; Hagenaars 1991). Therefore, scholars must guard against non-comparability and measurement 
error when observing these sensitive cross-national differences in poverty (Atkinson 1990). Also, cultural differences in the definitions of family units often obscured some of the national differences in poverty. Until recently, the scarcity of high quality data needed for such comparisons compounded these issues (Cantillion 1997). Hence, these methodological and data concerns must be carefully addressed in order to advance the comparative analysis of poverty.

Though cross-national differences are probably larger, historical differences remain important to the study of poverty as well. For example, assessing the trends in U.S. poverty remains a highly controversial issue (Betson and Warlick 1998; Jorgenson 1998). Understanding historical trends in poverty are also important for separating the effects caused by sheer demographic shifts versus other causal factors like social policy and long-run economic changes (Danziger and Weinberg 1994; Ruggles 1990). Though some research finds that poverty levels remain relatively stable over time within OECD nations, significant temporal variation does occur (Cantillion 1997). Fortunately, recent advances in data collection allow analysts to utilize more sophisticated measures to scrutinize over-time comparisons (Ravallion 1998).

Assessing comparative historical variation in poverty offers much for the sociology of poverty. To maximize our contribution, two issues bear careful consideration. First, given the difficulty in comparing poverty across societies and time, to make general inferences about causal processes, scholars need measures that grasp the same phenomena in each society. Second, given the diverse meanings, nature and content of poverty in various societies, scholars need to broaden the very definition of poverty. To assess what are essentially culturally specific and historically contextualized phenomena, scholars need a broad conceptualization of poverty. While seemingly contradictory, the next two sections argue that we need to embrace both concerns simultaneously. 


\section{RELATIVE VERSUS ABSOLUTE POVERTY MEASURES}

For many years, a vigorous debate persisted over relative versus absolute definitions of poverty (see Sen 1979, 1983; Madden 2000). Relative and absolute definitions of poverty tap into fundamentally divergent notions of difference and deprivation (Shanahan and Tuma 1994). Also, absolute and relative standards produce different policy implications and accounts of the experience of poverty, and somewhat differ in the extent of poverty (Townsend 1980). Despite this historically contentious debate, poverty scholars increasingly conclude that in advanced capitalist democracies, a relative definition is more appropriate (Atkinson 1998a; Gordon 1972; Hagenaars 1991; Madden 2000; Ravallion 1998; Sen 1992). Particularly relevant to such nations, relative measures usefully capture changes in necessities over time and place. Scholars also conclude that a relative measure more effectively gauges comparative historical variation across comparable nations in a historical period. Alternatively, absolute measures of "basic needs" are most useful in developing countries vulnerable to famine and underdevelopment. By reviewing the strengths and weaknesses of absolute and relative measures, this section establishes a relative standard as a criterion for an ideal measure of poverty.

\section{Absolute Measures of Poverty}

Absolute measures involve a cross-nationally and historically constant and fixed threshold, which distinguishes poor from non-poor. For example, except for inflationary adjustments, the U.S. measure is absolute over time, regions, and family types. Absolute measures assume that a certain material level purchases an essential bundle of goods necessary for well-being. For example, the World Bank defines poverty absolutely as living on less than one dollar per day. Thus, in developing countries, absolute measures can also be tied to absolute definitions of well-being, such as infant mortality, life expectancy, and caloric intake (e.g. 
Bradshaw et al. 1993). Sen (1992; 1999) argues that when studying developing countries, absolute measures should be retained. Nevertheless, absolute measures suffer from serious limitations that render them inappropriate for advanced capitalist democracies.

Importantly, scholars have grown skeptical that a fixed bundle of goods or absolute threshold of well-being can capture the complexity of poverty. This is exacerbated when an absolute standard is employed regardless of historical and national contexts (Atkinson 1998a;

Smeeding, O'Higgins and Rainwater 1990). ${ }^{7}$ Smeeding (the Director of LIS) and his colleagues avoid an absolute measure because it "conveys an unwarranted objectivity" (1993: 246). Further, they argue it has become "the widely held view among scholars working in this arena that a poverty standard cannot be established independently of the economic and social context within which needs arise and are defined" (Smeeding et al. 1993: 247). Due to these reasons, poverty measurement debates have moved away from absolute measures. While absolute measures effectively assess poverty in developing countries, relative measures are more appropriate in advanced capitalist democracies. Relative poverty measures cannot capture the absolute deprivation of households, but more accurately grasp the notion of relative deprivation.

\section{Relative Measures of Poverty}

Relative measures generate specific poverty thresholds for each society in each time period from patterns in the income distribution. Typically, relative measures begin with a threshold of 50 percent of the median income. People below such a threshold are considered too far down on the queue of the scarce resource of income to be fully integrated into society (Shanahan and Tuma 1994). Hence, relative measures reflect the difference in living conditions between the poor and the majority of society, rather than some abstract standard. While relative measures emerge from the distribution within a particular society, "Using a relative line does not 
amount to measuring inequality nor does it imply that poverty is by definition 'always with us"" (Foster 1998: 337).

A relative measure's greatest theoretical virtue is that it is entirely grounded in national and historical context (Townsend 1980). Relative measures advantageously measure deprivation according to a particular society's cultural norms and customary, prevailing standards of necessities (Sen 1979). As Adam Smith (1937) argued, poverty is a lack of those necessities that "the custom of the country renders it indecent for creditable people, even of the lowest order, to be without" (quoted in Ruggles 1990: xv). The scholar and activist Michael Harrington often argued that poverty should be gauged according to the living standards of the mainstream of contemporary society. ${ }^{8}$ Thus, relative measures frame poverty as a social and, hence, sociological condition. ${ }^{9}$

Theory aside, relative measures are also superior because they provide leverage for policy analysis and sociological research. In fact, several European poverty scholars argue for nation-specific relative measures over Europe-wide standards (e.g. Atkinson 1998a). Even U.S. policy makers have long conceded that as a society's standard of living rises, more expensive consumption is forced on the poor to remain integrated into society (President's Commission on Income Maintenance Programs 1969). For example, arguably the most important trends in children's poverty entail relative deprivation, since massive relative deprivation is what disadvantages children in human development, human capital and life chances. ${ }^{10}$ Relative measures are embedded in the social context and thus are far more valuable for sociological research on the causes and trends in poverty.

Although a growing consensus of poverty analysts prefers a relative measure, the debate between absolute and relative measures persists. Advocates of absolute measures concentrate on 
basic needs, because if those are unmet - in terms of physiological subsistence and safety poverty is truly present. Despite the persuasiveness of this claim, advocates of relative measures respond that the concept of "need" is actually relative itself - reflecting contextual norms of what is a "need" (Harrington 1981: 188). Ruggles (1990) argues that consumption patterns have changed so dramatically over the past 40-50 years that defining the basic needs of American families is quite elusive. Other scholars go even further in problematizing the concept of basic needs. Ravallion (1998: 21) notes that perceptions of "well-being" are contingent on the reference group's circumstances, and argues, "There is an inherent subjectivity and social specificity to any notion of 'basic needs." Hagenaars (1991: 141) stresses that even nutritionists cannot agree about levels of calories needed for various ages, sexes, occupations and living conditions, and contends "the resulting estimates are not as absolute and objective as they are claimed to be." While most scholars agree that a desperate absolute level of deprivation does exist, under which families are definitely poor, discerning an appropriate standard above that level remains ambiguous. Because such a minimal standard has limited utility in advanced capitalist democracies, most scholars argue that basic needs standards are less useful. Townsend (1980: 300) argues that, "Any rigorous conceptualization of the social determination of need dissolves the idea of 'absolute' need." Overall, relative measures emerge as superior.

While most scholars now agree on the use of a relative measure in operationalizing poverty, much theorizing and debate continues about the conceptualization of poverty itself. Arguably, the most promising theoretical direction for the analysis of poverty is the literature on social exclusion. While debates on social exclusion are prominent in Europe, the concept has not been fully integrated into the sociology of poverty in the U.S. 


\section{CONCEPTUALIZING POVERTY AS SOCIAL EXCLUSION}

Recently, poverty analysts have grown dissatisfied with narrow theoretical conceptualizations and measures of poverty. In fact, narrow perceptions of poverty may fundamentally underestimate the extent and severity of poverty (Townsend 1980). European scholars have advanced the concept of social exclusion as an attempt to broaden the conceptualization of poverty and to facilitate measurement innovations (Cantillion 1997; Ormerod 1998; Paugam 1998; Procacci 1998; Wacquant 1995). Conceptualizing poverty as social exclusion can provide a novel and beneficial direction for the U.S. sociology of poverty. Potentially, the concept social exclusion will suggest new sets of interesting sociological questions and provide different theoretical interpretations of old findings. Therefore, conceptualizing poverty as social exclusion is a criteria for an ideal measure of poverty.

Social exclusion is polysemic, having multiple meanings in different contexts and for different purposes (Silver 1994, 1995), yet important common elements can be identified. Social exclusion is the antithesis of the Durkheimian concept of solidarity and connotes marginalization and irrelevance. Theorists characterize social exclusion to entail "the multi-dimensional character of disadvantage and exclusion in modern market economies" (Cantillion 1997: 130); multiple deprivation or "cumulative misery" (Schuyt and Tan 1988: 14); those "who suffer from an accumulation of disadvantage which cannot be reached by macro-policies" (Dahrendorf 1990: 151); and, those difficult to reach with social policy (Engbersen 1991). The notion of social exclusion echoes Harrington's (1981: 11) classic concern that "the poor are losing their links with the greater world." In addition, social exclusion is consistent with Wilson's (1991) concept of social dislocation, which he describes as limited differential opportunities for economic resources, political privileges, organizational influence, and cultural experiences (see also 
Rankin and Quane 2000). Social exclusion can be understood as "people being prevented from participation in the normal activities of the society in which they live or being incapable of functioning" (Atkinson 1998a: 27). In sum, social exclusion means incomplete citizenship and unequal access to the status, benefits and experiences of typical citizens in society (Gore 1995).

While social exclusion has multiple meanings, the concept also reduces to one central notion. If one is socially excluded, that person has a limited capability to effectively participate in society. Capability refers to the ability to function effectively in society and have the freedoms to participate fully and equally with the mainstream of society. Capability offers a promising link between poverty and social exclusion, as social exclusion defines the lack of the basic capabilities that make one poor (Sen 1999). ${ }^{11}$ Sen (1992) has formulated his arguments about inequality and poverty around people's substantive freedom of choice to achieve valuable functionings and well-being. A functioning member of society must have basic freedoms (or capabilities) to participate in society's main institutions (Barry 1973, 1998). Thus, the concepts social exclusion and capability present an engaging, broadening direction for analysts of social inequality. To date, however, the connection to poverty measurement has not been fully articulated. I argue that social exclusion, and hence capability, facilitate the reconceptualization of poverty in two main ways.

First, these concepts explicitly and implicitly necessitate a relative measure of poverty. Explicitly, policy debates for relative poverty measures have been influenced by the concept of social exclusion (Barry 1998; Gore 1995). The notion of social exclusion has been deployed in the European debate about the community- and society-specific nature of poverty. In 1984, when the European Commission constructed measures of poverty, the Council of Ministers overtly linked their measures to social exclusion by defining poverty as "persons whose 
resources are so limited to exclude them from the minimum acceptable way of life in the Member State in which they live" (Atkinson 1998a: 2). Silver (1994) explains that the European Union's statistical service, Eurostat, and the Luxembourg Income Study utilize relative measures of poverty due to a theoretical interest in relative deprivation and social exclusion. Atkinson (1998b) adds that utilizing an absolute deprivation standard of poverty - with its emphasis on economic circumstances in isolation to others - has no relevance to social exclusion. Last, the empirical reality of "new" poverty within Europe explicitly corresponds to what French scholars label "exclusion," with its relative deprivation, insecurity, and displacement (Silver 1994).

Implicitly, relative measures are theoretically consistent with social exclusion. Social exclusion theorists have also been influenced by Rawls' difference principle. Atkinson (1987) explains that a Rawlsian theory of poverty is concerned with the "least fortunate group in society" and this group is the socially excluded who could be defined as poor. Rawls (1971) even suggested that this group could be defined as those with less than half of the median income and wealth, and noted that this could form a meaningful poverty standard. Finally, a theoretical interest in social exclusion necessitates an appreciation of cultural and historical context. In turn, cross-nationally operationalizing poverty or social exclusion is quite difficult and requires a relational measure that is grounded in social context (Silver 1994).

Second, social exclusion and the economic market are strongly connected. Because poverty is primarily an economic phenomena and social exclusion is multifaceted and complex, the two may seem incompatible. It may even seem inappropriate to treat social exclusion as a market phenomenon, rather than a cultural, institutional and social concept. However, the economic market is one of several main mechanisms triggering social exclusion. In postindustrial welfare states, a low level of economic resources is a principal precursor to social 
exclusion (Barry 1998). In effect, an interest in social exclusion demands an interest in economic inequality, and "A government professing itself concerned with social exclusion but indifferent to inequality is, to put it charitably, suffering from a certain amount of confusion" (Barry 1998: 22). The essence of social exclusion thus involves the dual marginalization by society's institutions and, especially the market (Gore 1995; Rodgers 1995). ${ }^{12}$

The link between social exclusion and the market, and hence poverty, is made even more clear by returning to capability. Sen (1992: 110) asserts that, "poverty is not a matter of low well-being, but of the inability to pursue well-being precisely because of the lack of economic means." Even with the nuanced concept of capability, a basic level of economic means is essential for escaping poverty. While this basic level of capability almost implies an absolute definition of poverty, this need not be the case. Though poverty is absolute in terms of capabilities, it is plausible, and even appropriate, that poverty is relative in terms of economic resources (Sen 1983; Ravallion 1998). Therefore, capability can be an absolute concept entailing

basic levels of social functioning, while being measured as a relative economic standing. ${ }^{13}$ Thus capability and social exclusion, as attributes of poverty, emerge from a relative measure of poverty.

\section{TAXES, TRANSFERS AND STATE BENEFITS}

One of the most persuasive critiques of the U.S. measure of poverty is that it neglects taxes, financial transfers, and in-kind benefits. Of course, taxes and transfers make a significant impact on a family's finances. In fact, the deteriorating value of transfers is the main reason for the worsening of child poverty in recent decades in the U.S. (Lichter 1997). Further, taxes on U.S. poor families have steadily risen, and in turn, their financial standing is actually weaker than prior equivalent families. This neglect of taxes and transfers in configuring income violates 
Sen's (1976: 219) Transfer axiom, "Given other things, a pure transfer of income from a person below the poverty line to anyone who is richer must increase the poverty measure." Ignoring these financial costs and benefits when measuring poverty is a fundamental theoretical and empirical problem (Ravallion 1998). Thus, ideal poverty measures must incorporate taxes and transfers and measure poverty before and after taxes and transfers (Danziger et al. 1981).

Though taxes and transfers most often are financial, the contribution of in-kind and nearcash benefits like housing assistance and food-stamps is essential (Townsend 1980). Poverty analysts often ignore state benefits when assessing family income because problems in measurement, valuation, and imputation of near and non-cash income to individual households are quite formidable. This is troubling since these benefits affect the distribution of well-being between households, and since ignoring these benefits yields misleading inferences about the relative well-being of various types of households (Smeeding et al. 1993).

Under the assumption that the most comprehensive definition of income is optimal for assessing familial welfare, the LIS analysts have made significant strides in incorporating taxes and transfers into their measures of income. Smeeding and his colleagues have assessed the value of, and imputed near-cash income to a variety of benefits. These benefits provide significant resources for families, and cumulatively have significant equalizing consequences by raising living standards and reducing poverty. While national differences exist in the nature and extensiveness of these benefits, their importance to the income distribution is universal.

Importantly, these benefits accrue from both the government and the private sector. Though government benefits typically provide larger consequences for the overall income distribution, private benefits are nontrivial. To be most effective, poverty should be examined both as it is generated in the private sector, and as it is mediated by the state. ${ }^{14}$ To the extent 
possible, private benefits should be considered as part of market income, and state benefits should be considered as part of ultimate state mediated income. Both types of income - before and after taxes and transfers - are important to understanding the complex nature of poverty.

\section{THE ORDINALIST REVOLUTION}

Following Sen’s (1976) pioneering work, “The Ordinalist Revolution” (Hagenaars 1991) fundamentally redirected debates on poverty measurement. While only minimally impacting public policy (Osberg and Xu 2000), consideration of Sen's contribution is essential for any serious evaluation of poverty measurement. The contribution can best be explained by considering a series of measures that build on one another. Table 3 displays each measure that is relevant to this explanation. All of the measures discussed can be defined relatively.

\section{*** Table 1 About Here ***}

First, poverty is measured commonly with a Headcount (denoted by $\mathbf{H}$ ), the percentage of the population that is below a certain threshold of income. $\mathbf{H}$ is a simple dichotomous measure of poverty, offering an either/or account of who is denied the basic minimum rights of citizenship or social inclusion (Atkinson 1998a). Despite its useful simplicity, $\mathbf{H}$ has received mounting criticism (Atkinson 1987). Sen (1976: 219) calls H "crude" because it ignores the income distribution of the poor and contains no information on the depth of poverty. Sen (1976: 219) articulated this basic criticism of $\mathbf{H}$ as the "Monotonicity Axiom: Given other things, a reduction in income of a person below the line must increase the poverty measure." 15 Though it still has utility for describing the proportion of the population that is socially excluded, $\mathbf{H}$ is generally considered an imperfect measure of poverty (Myles and Picot 2000).

To address these concerns, one may estimate the depth of poverty of the poor. Conventionally, depth is measured as the poor's average difference from either the median of 
income or the threshold of poverty (Kakwani 1993). This average deprivation, the Income Gap (denoted by I), is normally standardized by the median income or threshold of poverty to render it comparable across populations. By considering $\mathbf{I}$, rather than simply $\mathbf{H}$, scholars more realistically capture the continuous quality of poverty. In reality, poverty is not a discrete condition that is immediately acquired or shed by crossing any particular income line (Watts 1968). Rather, poverty is an interval variable, as the desperately poor with zero income are worse off than the poor just below the poverty threshold.

Still though, $\mathbf{I}$ is imperfect as well. While $\mathbf{H}$ offers information on the percentage of the population that is poor, I details the depth of poverty of this sub-population. In turn, $\mathbf{H}$ is insensitive to the depth of poverty, while $\mathbf{I}$ is insensitive to the quantity of poor (Sen 1976). As a result, scholars have created new poverty measures by simply taking the product of $\mathbf{H}$ and $\mathbf{I}$, that is HI (Atkinson 1987). Because it treats poverty as continuous, unlike the dichotomous $\mathbf{H}, \mathrm{I}$ label $\mathbf{H I}$ the Interval Measure. Both $\mathbf{H}$ and $\mathbf{I}$ are equally important components as neither individually tells the whole story about poverty intensity (Osberg and Xu 2000). ${ }^{16}$

At this point, Sen (1976) offered his key contribution. He imposed Axiom R, that the poverty gap (I) should be weighted to correspond to the rank order in the interpersonal welfare ordering of the poor (see also Shorrocks 1995). Sen argued that HI should be weighted such that the income gaps of the poorest of the poor had more influence. In effect, HI should add a weight for the income inequality among the poor. The Interval Measure was augmented to form the Ordinal Measure of poverty (denoted by $\mathbf{O}$ ), with the following formula:

$$
\mathbf{O}=\mathbf{H} * \mathbf{I} *(\mathbf{1}+\mathbf{C V}) \text {, where } \mathrm{CV} \text { is the inequality among the poor }{ }^{17}
$$

While more mathematically complicated versions of this formula exist (e.g. Kakwani 1993; Sen 1986), several scholars have demonstrated that the Ordinal measure can be reduced in this way 
(Myles and Picot 2000; Osberg and Xu 2000). Additionally, with this formula, $\mathbf{O}$ is easily decomposed into three parts that can be analyzed separately to understand their specific changes and relative influence.

As a final alternative, I have created the Sum of Ordinals Measure of poverty (SO). SO is simply the sum of headcounts for seven different thresholds, and thus builds on relational distribution measures of inequality (Handcock and Morris 1998). Specifically, I calculated $\mathbf{H}$ for $60,50,40,30,20,10$ and 5 percent of the median income, and summed the values. The SO measure mimics the properties of $\mathbf{H I}$, and can be easily converted to something similar to $\mathbf{O}$ by weighting the lower thresholds $(5,10$, and 20 percent $)$ more greatly.

Overall, Sen's work provoked a fundamental rethinking of poverty measurement. In addition to the Headcount $(\mathbf{H})$ or Income Gap (I), scholars can now use three more sophisticated measures of poverty: the Interval (HI), Ordinal (O) and Sum of Ordinals (SO). Each offers fruitful direction for sociological research on poverty. ${ }^{18}$ As Table 1 displays, each measure has advantages and disadvantages, which upon consideration assist measure selection. If an analyst seeks a simple, parsimonious measure that incorporates both the quantity and depth of poverty, HI is preferred. By contrast, if one decides that the deeply poor should disproportionately affect the index, $\mathbf{O}$ should be used. Unlike $\mathbf{H I}, \mathbf{O}$ weights the index with the inequality among the poor and reflects the judgment that the deeply poor are more important than those near the threshold. Of course, many analysts may not agree with this judgment. Additionally, some evidence exists that the variation in $\mathbf{O}$ not captured by $\mathbf{H I}$ is empirically unimportant (Osberg and Xu 2000; Myles and Picot 2000). Hence, $\mathbf{O}$ often adds unneeded complexity that may obscure national comparisons of poverty (Atkinson 1987; Hagenaars 1991). Therefore if one seeks a sufficient yet parsimonious measure and prefers to avoid the complexity and assumptions of $\mathbf{O}, \mathbf{H I}$ may be 
the best alternative. Finally, if one seeks to graphically represent descriptive analyses of the poor, SO offers advantages. Unlike HI or $\mathbf{O}$, SO provides a clear, interpretable display of patterns in the distribution of the poor (see Figure 1 below). Of course, $\mathbf{S O}$ has the disadvantage of being a less precise measure than $\mathbf{H I}$ or $\mathbf{O}$. In sum, analysts gain much by considering these multiple measures of poverty. Depending on a scholar's theoretical interests, each measure carries certain advantages and disadvantages. Generally, though, an ideal measure of poverty should integrate the depth of poverty and the inequality of the poor.

To summarize, this discussion provides five criteria for ideal measures of poverty. Each of these criteria emerges from an existing theoretical literature that has fully established their relevance to poverty measurement. Table 2 displays these criteria in summary form.

*** Table 2 About Here ***

\section{U.S. SOCIOLOGY AND THE MEASUREMENT OF POVERTY}

Given the influence of these advances across the social sciences and internationally, it seems plausible that sociologists would incorporate them as well. Certainly, as the sociology of poverty grows, these techniques potentially offer leverage for research on poverty. But, have sociologists utilized these advances in their work? Specifically, what are the patterns in the sociological literature regarding the measurement of poverty? I answer these questions with a content analysis of major U.S. sociology journals. As Table 3 displays, I analyzed every quantitative sociological study published from 1990 through 2001 in seven relevant journals: American Journal of Sociology, American Sociological Review, Demography, Research in Social Stratification and Mobility, Social Forces, Social Problems, and Social Science Research. In sum, I examined 53 articles that featured poverty as a dependent or key independent variable. 
*** Table 3 About Here ***

The vast majority of sociological studies use the official U.S. measure (69.8\%). This is surprising given that several important critiques of this measure were published prior to or in 1990 (e.g. Ruggles 1990), and since Wilson's (1991) 1990 ASA Presidential address criticized the U.S. measure and called on sociologists to conceptualize poverty as social dislocation. Unfortunately, sociologists continue to use the measure despite its problems, and prominent calls for change. Particularly problematic, some studies attempt to analyze historical variation in poverty with the U.S. measure, despite its temporal unreliability (e.g. Eggers and Massey 1992). 11.3 percent made modest alterations to the U.S. measure, including measuring the percentage of the population below 125 percent of the official threshold. 9.4 percent of studies included a broader scale where the U.S. measure was one of several indicators (e.g., South and Crowder 1999). Also, a few studies examined the U.S. measure in combination with other measures of poverty (e.g. Eggebeen and Lichter 1991). Though these last few studies provide some improvement to the flawed U.S. measure, they are few and far between. Plausibly, it might be better to change our measurement strategies altogether rather than attempting to modify this flawed indicator.

While my approach departs from their strategies, some sociologists have produced innovative alternatives to the U.S. measure. 22.6 percent examine recipiency of welfare programs (e.g. AFDC) as a proxy for poverty (e.g. Harris 1993; McLeod and Shanahan 1993). 7.6 percent of studies examine severe poverty, including families with less than half of the U.S. measure. A slightly larger percentage (15.1\%) assessed long-term poverty (e.g. Devine et al. 1992; Quillian 1999). Finally, eight studies (15.1\%) avoid criticisms of poverty measures, by simply measuring income, as an ordinal or interval variable, and studying low-income families 
(e.g. Brooks-Gunn et al. 1993; Duncan et al. 1998; Huff-Corzine et al. 1991; Lichter and Eggebeen 1993; Wu 1996). Compared to most sociological studies, these more effectively embrace issues of relative deprivation, social exclusion, and capability. Still, I would argue that these studies do not quite sufficiently incorporate advances in the measurement of poverty.

A smaller number of articles incorporate some of the aforementioned theoretical advances. 9.4 percent of studies utilize a relative measure of poverty. Not surprisingly, three of the four papers that examine comparative international variation in poverty also utilize a relative measure (e.g., Casper et al. 1994; Kenworthy 1999). The sheer paucity of sociological studies examining comparative international variation is unfortunate. The U.S. remains the predominant case of study for U.S. sociologists of poverty, despite its relatively unique and potentially anomalous position in the global economy. Just under ten percent of sociological studies also include a post-tax or post-transfer measure of poverty (e.g. Butler 1996; Duncan and Rodgers 1991). It is equally problematic that more sociologists do not examine post-tax and transfer income since this is the prime criticism of the validity of the U.S. measure. Last, unfortunately, no sociological study utilizes a measure that incorporates inequality among the poor. The complete neglect of Sen's Ordinal Revolution is a serious omission in sociological research.

Overall, there is a fair amount of diversity in the sociological measurement of poverty, with several scholars incorporating innovative and useful techniques. Further, several studies acknowledge important advances in poverty measurement and make note of the many conceptual and methodological limitations of the U.S. measure (e.g. Eggebeen and Lichter 1991). However, on the whole, sociological research has not sufficiently integrated the theoretical and methodological advances in poverty measurement. While it is unlikely that this content analysis is fully exhaustive of all sociological research on poverty, the coverage of seven journals and 
twelve years provides an illustration of the dominant patterns in the sociology of poverty. By and large, U.S. sociologists too often rely on the problematic U.S. measure. ${ }^{19}$ Despite the very important contributions of sociological research, our collective potential for scholarly and policy debates is probably limited by these measurement deficiencies.

\section{DATA AND METHODS}

Selecting poverty measures has consequences for social policy priorities and theoretical conclusions (Atkinson 1998a; Hagenaars 1991; Haveman 1987). My efforts center around establishing criteria and developing measures that are accessible, statistically defensible and methodologically feasible (Atkinson 1987; Citro and Michael 1995). To further evaluate these measures, I conducted a series of analyses with the Luxembourg Income Study (LIS). The LIS provides cross-nationally and historically comparable individual-level data sets. Cumulatively, LIS provides almost standardized data - what the LIS staff call "Lissifed" data with similar variables across data sets, similar samples and equalizing weights, which all allow for population estimates (Cantillion 1997). Of course, the LIS data is not perfect and has important methodological limitations (see the LIS web page: www.lisproject.org). However, the advantages outweigh the disadvantages, and the LIS has great capability to advance the comparative historical scholarship of inequality and poverty. To get estimates of poverty, I first conducted analyses with 74 different data sets to compute a poverty statistic in a given country in a given year. This analysis generated data on 20 countries with between one and seven time points each, resulting in an unbalanced sample of $72-73$ cases. $^{20}$

The LIS contains data on income, but not wealth or consumption. However, for theoretical (see Hagenaars 1991) and practical purposes (see Sen 1992), income may be preferable to wealth for this type of analysis. People have reasonably good records of income 
because of taxation, but less high quality data exists on wealth and people simply do not have good records of consumption (Ruggles 1990). ${ }^{21}$ Following the practices of other LIS analysts (e.g. Smeeding et al. 1993), I concentrate on two measures of income: Market Generated (MG) income and State Mediated (SM) income. MG includes all sources of income prior to government taxes and transfers and SM includes all sources of income after taxes and transfers

(DPI in LIS). ${ }^{22}$ Also, LIS assigns value to near-cash benefits to provide a more comprehensive measure of income. ${ }^{23}$

Following convention in poverty research (Atkinson 1987; Townsend 1980) and among LIS analysts, I standardize the income threshold for poverty by family size with an “equivalence scale." While there is much debate over different scales (see Triest 1998), the LIS staff examined the statistical behavior of over 30 different scales and concluded that one simple formula reasonably approximates all others (see Buhmann et al. 1988). Accordingly, I use this equivalence scale, which was adopted by the Organization for Economic Cooperation and Development (OECD) (Atkinson 1998a). The OECD scale weights the head of the household as one, additional adults as .5 , and children as .3 , owing to the differential demands on a household's resources that heads, other adults and children require.

\section{EMPIRICAL ANALYSES}

The following empirical analysis explores the consequences of different poverty measurement decisions. By demonstrating that different measures of poverty result in different empirical patterns, this analysis illustrates how more sophisticated measures of poverty provide new and plausibly more accurate information on poverty (Ruggles 1990).

Table 4 displays the descriptive statistics for the poverty measures and their related components for 72-73 observations. Besides the mean and standard deviation, I also list the 
coefficient of variation (CV). For all poverty measures and components, I report Market Generated Poverty (MG) and State Mediated Poverty (SM). *** Table 4 About Here ***

Consistent with past research and the European Union's threshold of 50 percent of the mean income (Atkinson 1998a), the headcount $(\mathbf{H})$ is computed as 50 percent of the median income. Unsurprisingly, market generated $\mathbf{H}$ is considerably higher than state mediated $\mathbf{H}$. Owing to the vast comparative-historical variation in the generosity of welfare states, the $\mathrm{CV}$ for $\mathbf{H}$ is also much larger for SM poverty, indicating greater variation in $\mathbf{H}$ after considering taxes and transfers. The Poverty Income Gap (I) is computed by subtracting the average poor household's income from the median, and standardizing over the median. Like $\mathbf{H}$, state mediated $\mathbf{I}$ is smaller than market generated $\mathbf{I}$, and again the state mediated $\mathbf{C V}$ of $\mathbf{I}$ is larger than the market generated $\mathrm{CV}$ of $\mathbf{I}$ for MG. Because $\mathbf{H}$ and $\mathbf{I}$ are smaller for state mediated poverty, it is clear that the welfare state reduces the number of poor, and the depth of poverty. In turn, state mediated Interval Poverty (HI) is much smaller than market generated Interval Poverty (HI), since $\mathbf{H I}$ is simply the product of $\mathbf{H}$ and $\mathbf{I}$ separately. As with the two components, the $\mathrm{CV}$ of state mediated $\mathbf{H I}$ is much larger than the $\mathrm{CV}$ of market generated $\mathbf{H I}$. While state mediated $\mathbf{H I}$ poverty is significantly smaller than market generated $\mathbf{H I}$, greater variation exists across countries and years, in state mediated $\mathbf{H I}$ than market generated $\mathbf{H I}$.

To calculate Ordinal poverty, I estimated the inequality among the poor. After censoring the sample above 50 percent of the median income, I calculated the coefficient of variation (CV) of income for the sub-sample of the population that was poor. Thus, CV in this case refers to the dispersion of income among the poor. Since many people have no market income, market generated $\mathrm{CV}$ of income is much larger than state mediated $\mathrm{CV}$ of income. To calculate the 
Ordinal Measure of poverty $(\mathbf{O})$, I synthesized CV of income for poor households with the Interval measure of poverty (see above). Consistent with the components, market generated $\mathbf{O}$ is much greater than state mediated $\mathbf{O}$, and the $\mathrm{CV}$ of state mediated $\mathbf{O}$ is slightly larger than market generated $\mathbf{O}$. Whether utilizing $\mathbf{H}, \mathbf{I}, \mathbf{H I}$ or $\mathbf{O}$, state mediated (SM) poverty is more dispersed yet smaller than market generated (MG) poverty. As with the others, MG SO is much larger than SM SO, despite more dispersion in SM SO relative to MG SO.

Table 5 displays MG poverty statistics and the comparative ranking of 16 nations circa 1995 (ranked such that 1 has the most poor, and 16 has the least poor). Nations like Belgium, Denmark and Italy consistently have more poverty, while countries like Finland, Switzerland, and Canada have markets that generate less poverty. Importantly, the ranking of countries substantially changes depending on the measure. For example, though Sweden has the third most poverty according to the simple headcount measure $(\mathbf{H})$, they drop to having the sixth most poverty upon considering the income gap (I) and using the interval measure (HI). Further, they fall to having the eleventh most poverty according to the Ordinal measure $(\mathbf{O})$, owing to the small inequality among the poor (CV). In another example, Luxembourg has the fifteenth most poverty with $\mathbf{H}$, but slides to having the twelfth most poverty with $\mathbf{H I}$, and the ninth most poverty with $\mathbf{O}$.

\section{*** Table 5 About Here ***}

Though some consistencies exist, the rank ordering of MG poverty is sensitive to the measure employed. Table 5 also includes the correlation coefficients between $\mathbf{H}$ and the other measures for the full sample of cases. While $\mathbf{H}$ is highly correlated with $\mathbf{H I}$ and $\mathbf{S O}$, it is less highly correlated with $\mathbf{I}$, the $\mathrm{CV}$ and $\mathbf{O}$. Even though high correlations exist, this is mostly due to the limited dispersion in Income Gap (CV of .054, see Table 4). Because $\mathbf{H}$ is only modestly 
correlated with $\mathbf{I}$ and $\mathrm{CV}$, it is important that scholars utilize $\mathbf{H I}$ or $\mathbf{O}$ if they are interested in the depth or inequality among the poor. Finally, Table 5 reveals weaker but similar patterns in the correlation between the rankings of the 16 nations with $\mathbf{H}$, and the other measures.

Table 6 displays SM poverty data for 16 nations circa 1995. Again, the rank ordering of nations is equally sensitive to particular measures. Consistent with previous research, countries like the U.S. and Australia have the most poverty, and Finland and Luxembourg have the least. However, important departures from this pattern appear. Though having the tenth most headcount $(\mathbf{H})$ poverty, the high income gaps and inequality among the poor significantly elevate Denmark and the Netherlands in terms of Interval $(\mathbf{H I})$ or Ordinal $(\mathbf{O})$ poverty. Also, Canada and Spain have much less poverty with $\mathrm{HI}$ or $\mathrm{O}$ than with the simple $\mathbf{H}$. It is commonly asserted that liberal nations like the U.S., Australia and Canada have much more SM poverty and much less MG poverty, whereas European encompassing welfare states like the Netherlands, Sweden and Denmark exhibit the opposite pattern (Smeeding et al 1993; Korpi and Palme 1998). However, upon close examination of more sophisticated measures of poverty, this simple pattern is considerably more complex.

*** Table 6 About Here ***

Also, Table 6 reports the correlation coefficients between $\mathbf{H}$ and other measures, with the entire sample, and the correlation in ranking between $\mathbf{H}$ and other measures, with the sub-sample of 16 nations. For SM poverty, $\mathbf{H}$ is highly correlated with $\mathbf{H I}$ and SO, is less but strongly correlated with $\mathbf{O}$, and is not correlated with $\mathbf{I}$ and CV. Though the measures follow similar patterns, the stark non-correlation between $\mathbf{H}$ and $\mathbf{I}$ and $\mathrm{CV}$ suggests that if a scholar is interested in the depth and inequality among the poor, it is wise to utilize HI, $\mathbf{O}$ or SO. With the rank ordering of nations, the correlation between $\mathbf{H}$ and other measures is less strong but similar. 
Some readers may contend that these differences in ranking are small and given the high correlations among measures, the simple $\mathbf{H}$ is still an adequate measure of poverty. To further consider this matter, I display in Figure 1 four cases with similar SM H poverty. Italy (1986) at 10.6, Switzerland (1992) at 10.3, and the U.K. in 1974 at 10.7 and at 10.6 in 1995 have practically indistinguishable rates of poverty. However, a closer examination of one higher and five lower thresholds - to construct $\mathbf{S O}$ and thus including similar information to $\mathbf{H I}$ and $\mathbf{O}$ reveals much greater variation. Switzerland has much deeper and more poverty than Italy and the U.K., while poverty increased considerably between 1974 and 1995 in the U.K. Further, though according to H, the U.K. in 1974 would have the most poor and Switzerland would have the least; these countries reverse with a more sophisticated measure (i.e., U.K.'s SO is 33.3 and Switzerland's SO is 52.8). Such vivid cases illustrate the potentially important role that $\mathbf{H I}, \mathbf{O}$ or SO would serve in capturing the complexity and depth of poverty ignored by $\mathbf{H}$. If scholars are interested in the poverty rankings of countries, it is essential that more rigorous measures be utilized and that multiple measures are evaluated (Atkinson 1987; Cantillion 1997). *** Figure 1 About Here ***

While cross-national variation in poverty is greater, historical trends are important as well. The U.S. provides an informative case to explore historical trends in poverty (see Table 7). With the official U.S. measure, poverty increased 18.8 percent between 1974 and 1997. This trend included small increases between 1974 and 1979, 1986 and 1991, 1991 and 1994. This trend also included a dramatic increase between 1979 and 1986, and a large decrease between 1994 and 1997. However, with more sophisticated measures, the trends in U.S. poverty are more complex. Because the U.S. measure does not fully include taxes and transfers, a comparison with the Market Generated Interval is useful. With the MG HI measure, poverty increased a 
more modest 6.7 percent over the period. Also, while the years with the most and least poverty remain the same, the third and fourth worst years reverse with the MG HI measure. In short, a relative measure incorporating the income gap has different trends than the U.S. measure.

\section{*** Table 7 About Here ***}

As discussed above, the U.S. measure is flawed because it ignores taxes and transfers, so a comparison with the State Mediated Interval (SM HI) measure is also valuable. With the U.S., poverty increased an even more modest amount of 2.8 percent with SM HI over the period. In addition, contrary to the U.S. measure, with SM HI, poverty actually declined between 1974 and 1979 and between 1986 and 1991. Owing to differences in the depth of poverty and taxes and transfers, factors unobserved with the U.S. measure, SM HI exhibited very different trends. If interested in the inequality among the poor (CV), one should also consider the State Mediated Ordinal measure (SM O). With SM O, poverty increased only a very small 1.5 percent between 1974 and 1997. Again, with SM O, poverty actually declined between 1974 and 1979 and between 1986 and 1991. As an alternative, one can examine the State Mediated Sum of Ordinals and find similar patterns to SM HI and SM O, with some shuffling of which years had more poverty. Clearly, the perceived dramatic increase in U.S. poverty observed by the U.S. measure is an artifact of measurement error. More realistically, the increase was much smaller, somewhere between 1.5 and 6.7 percent. Replicating the decline in poverty between 1974 and 1979 and 1986 and 1991 with three measures establishes these trends as actual, and vividly demonstrates the problems with the U.S. measure. Different historical patterns emerge with different measures, and a false understanding emerges with the U.S. measure.

As one final example of the problems of the U.S. measure, one can compare the quantity of households that would be misclassified with the U.S. measure. As mentioned earlier, studies 
have demonstrated sizable differences between the rates of poverty with the U.S. measure and the NRC's alternatives (Hill and Michael 2001; Uchitelle 1999). With the measures proposed in this paper, important differences materialize as well. As Table 7 indicates, 13.3 percent of the U.S. population was officially classified as poor in 1997 . With the market generated $\mathbf{H}, 30.1$ percent of the population would be poor. This rate, which is more than twice as high, provides the closest comparison since the U.S. measure does not consider taxes and transfers fully. Considering the impact of taxes and transfers on household income, a state mediated (SM) $\mathbf{H}$ provides a more realistic picture of familial income. The SM H for the U.S. in 1997 was 17.6 percent, hence the official U.S. measure inappropriately classified 4.3 percent of U.S. households as not poor. With a more theoretically and methodologically defensible measure, the U.S. rate of poverty in 1997 would have been 4.3 percent higher. Overall, the official U.S. measure provides inaccurate trends over time and clearly underestimates the extent of poverty in the U.S.

\section{IMPLICATIONS FOR FUTURE RESEARCH}

These advances in the measurement of poverty potentially offer much for sociological research on poverty. Plausibly, sociologists have not incorporated these advances for a number of reasons. Myles and Picot (2000) argue that these advances have not received wider circulation in part because of the highly technical, mathematical quality of the literature. Further, others may mistakenly presume that these measures are not replicable or comparable with different data sets or contexts. Many analysts probably avoid these measures in order to avoid arguing first principles and justifying what reviewers might view as controversial.

Ultimately, I presume that the official U.S. measure maintains legitimacy for sociological readers and convenience for sociological analysts. None of these concerns, however, need prohibit sociologists from developing and using more sophisticated measures of poverty. 
In pursuit of this goal, I advocate for three alternative measures of poverty. These three measures, the Interval (HI), Ordinal (O) and Sum of Ordinals (SO), emerge directly from the recent literature on poverty measurement and meet the aforementioned criteria. Unlike much of the previous literature, my discussion has been intentionally less technical in order to disseminate these advances to a wider audience. As mentioned earlier, each of the measures carries certain advantages depending on one's research interests. To adhere to Sen's Axiom R, analysts should use O; for graphical representations, analysts should use SO; and, for a simple, parsimonious adherence to the five criteria, analysts should use HI. Utilizing these measures, sociologists of poverty can proceed in a number of directions.

First, for additional analyses of the amount of societal poverty, I have supplied further data on different poverty measures. Table 8 displays estimates on the remaining cases available with the Luxembourg Income Study as of May 2002. I have calculated the MG HI, SM HI, MG SO, SM SO, MG $\mathbf{O}$ and SM $\mathbf{O}$ measures for 74 total observations. This data set includes 18 OECD nations and covers the historical period 1967 to 1997 . Hopefully, with the publication of these results, other scholars will utilize these estimates for analyses of the causes and consequences of comparative historical variation in poverty. Second, other individual-level data sets can easily produce these measures of poverty. Analysts can easily calculate these measures with basic descriptive statistics on the entire sample and the sub-sample of households that are below 50 percent of the median income. ${ }^{24}$ Future analysts should replace the U.S. measure with a relative measure that incorporates the depth of poverty. ${ }^{25}$ Of course, though not all data sets will have the detailed information on income that the LIS provides, analysts can estimate relative measures of poverty with as much information as possible. Overall, analysts will find that 
constructing and utilizing these more sophisticated measures of poverty is quite simple. Because these measures are easy to incorporate, sociologists should use them in future research.

*** Table 8 About Here ***

\section{CONCLUSION}

This paper seeks to advance the sociological measurement of poverty. Unfortunately, much of sociology still relies on the U.S. measure despite serious methodological problems. These methodological limitations are crucial and probably limit sociology’s collective contribution to the understanding of the causes and effects of poverty. As an alternative, I argue that scholars should cultivate measures of poverty that meet five criteria. First, scholars should utilize measures of poverty that effectively gauge comparative historical variation. Second, analysts should measure poverty as relative rather than absolute. Third, poverty should be conceptualized as social exclusion. Fourth, poverty indices should measure the depth and inequality among the poor. Finally, analysts should incorporate taxes, transfers and state benefits when calculating household resources. These criteria reflect theoretical and methodological developments that will be useful for sociology. For sociological research on poverty to advance, it is essential that scholars embrace and incorporate these developments.

This paper also provides an empirical analysis of patterns with three alternative measures: the Interval, Ordinal and Sum of Ordinals. The empirical analysis with the LIS data demonstrates that the amount and the cross-national ranking of poverty fluctuate with the particular measure used. Further, simple headcount measures produce limited and potentially less accurate information about comparative and historical variation in poverty. In an analysis of poverty in the U.S. since the early 1970s, the U.S. measure clearly provides inaccurate results about trends. With State Mediated poverty, the Interval, Ordinal and Sum of Ordinals measures 
display important declines in poverty that are not captured with the U.S. measure. Further, the U.S. measure misdiagnoses the increase in poverty since the early 1970 s. To understand the causal mechanisms driving poverty, it would be valuable for scholars to consider multiple measures and utilize one of these more sophisticated measures.

If sociologists seek to make scientific inferences and inform public policy, it is imperative that new measures of poverty be developed and integrated into the discipline. At present, the contribution of U.S. sociology is probably limited by the reliance on the U.S. measure and, in the few comparative studies, on a simple headcount measure. While the sociology of poverty has grown considerably over the past few decades, the discipline remains unfortunately out of step with advances in poverty measurement. Further, in the 1990s, the sociology of poverty cultivated increasingly sophisticated statistical analyses of poverty, yet left the more fundamental issue of measurement largely neglected. Plausibly, the sociology of poverty would benefit more by first scrutinizing the basic and primary methodological concern of measurement before proceeding with increasingly sophisticated statistical analyses of the causes and consequences of poverty.

Altogether, these criteria and alternative measures of poverty create a potentially fruitful new direction for research in sociology. With this redirection, it is possible that sociology could experience a second reinvigoration of research on poverty. This paper seeks to facilitate this second reinvigoration and encourage sociology to benefit from more sophisticated measures of poverty that are grounded in theoretical and methodological advances. 


\section{REFERENCES}

Alderson, Arthur S. and Francois Nielsen. 1999. "Income Inequality, Development and Dualism: A Reconsideration.” American Sociological Review 64: 606-631.

Allison, Paul D. 1978. "Measures of Inequality." American Sociological Review 43: 865-880.

Atkinson, Anthony B. 1998a. Poverty in Europe Malden, MA: Blackwell. . 1998b. "Chapter One: Social Exclusion, Poverty and Unemployment." Centre for Analysis of Social Exclusion, CASE Paper, No. 4, January. . 1990. "Introduction.” Pp. XVII-XXV in T. Smeeding, M. O’Higgins, L. Rainwater (eds.), Poverty, Inequality, and Income Distribution in Comparative Perspective Washington, D.C.: The Urban Institute Press. . 1987. "On the Measurement of Poverty." Econometrica 55: 749-764.

Barry, Brian. 1998. "Social Exclusion, Social Isolation and the Distribution of Income." CASE Paper No. 12. Centre for Analysis of Social Exclusion, London School of Economics, London. . 1973. The Liberal Theory of Justice Oxford: Clarendon Press.

Betson, David M., and Jennifer L. Warlick. 1998. "Alternative Historical Trends in Poverty.” American Economic Review 88: 348-351.

Blank, Rebecca M. 1997. It Takes a Naion Princeton, NJ: Princeton University Press.

Bradshaw, Jonathan. 2000. "Prospects for Poverty in Britain in the First Twenty-Five Years of the Next Century." Sociology 34: 53-70.

Bradshaw, York, Rita Noonan, Laura Gash, and Claudia Buchmann-Sershen. 1993. "Borrowing Against the Future: Children and Third World Indebtedness." Social Forces 71: 629-656. 
Brady, David, and Michael Wallace. 2001. "Deindustrialization and Poverty: Manufacturing Decline and AFDC Recipiency i in Lake County, Indiana, 1964-1993.” Sociological Forum 21 (2): 321-358.

Brooks-Gunn, Jean, Greg J. Duncan, Pamela Kato Klebanov, and Naomi Sealand. 1993. "Do Neighborhoods Influence Child and Adolescent Development?” American Journal of Sociology 99: 353-395.

Buhmann, Brigitte, Lee Rainwater, Guenther Schmaus, and Timothy M. Smeeding. 1988. "Equivalence Scales, Well-Being, Inequality, and Poverty: Sensitivity Estimates Across Ten Countries Using the Luxembourg Income Study (LIS) Database.” Review of Income and Wealth 34: 115-142.

Butler, Amy C. 1996. "The Effect of Welfare Benefit Levels on Poverty Among Single-Parent Families." Social Problems 43: 94-115.

Cantillion, Bea. 1997. “The Challenge of Poverty and Exclusion.” Pp. 115-166 in Social Policy Studies No. 21: "Family, Market, and Community: Equity and Efficiency in Social Policy.” Paris, France: OECD.

Casper, Lynne M., Sara S. McLanahan and Irwin Garfinkel. 1994. "The Gender-Poverty Gap: What We Can Learn From Other Countries.” American Sociological Review 59:594-605.

Citro, Constance, and Robert T. Michael. 1995. Measuring Poverty: A New Approach Washington, DC: National Academy Press.

Cox, W. Michael and Richard Alm. 1999. Myths of Rich and Poor NY: Basic Books. Dahrendorf, Ralf. 1990. The Modern Social Conflict - An Essay on the Politics of Liberty Berkeley, CA.: The University of California Press. 
Danziger, Sheldon D., Robert H. Haveman, and Robert Plotnik. 1981. "How Income Transfers Affect Work, Savings and Income Distribution.” Journal of Economic Literature 19: 975-1028.

Danziger, Sheldon H. and Daniel H. Weinberg. 1994. "The Historical Record: Trends in Family Income, Inequality, and Poverty." Pp. 18-50 in Confronting Poverty: Prescriptions for Change, edited by S.H. Danziger, G.D. Sandefur, and D. H. Weinberg. New York: Russell Sage Foundation.

Devine, Joel A., Mark Plunkett, and James D. Wright. 1992. "The Chronicity of Poverty: Evidence from the PSID, 1968-1987.” Social Forces 70: 787-812.

Duncan, Greg J., W. Jean Yeung, Jeane Brooks-Gunn, and Judith R. Smith. 1998. "How Much Does Childhood Poverty Affect the Life Chances of Children?" American Sociological Review 63: 406-423.

Duncan, Greg J,. and Willard Rodgers. 1991. “Has Children’s Poverty Become More Persistent?” American Sociological Review 56:538-550.

Eggebeen, David J., and Daniel T. Lichter. 1991. "Race, Family Structure, and Changing Poverty Among American Children.” American Sociological Review 56:801-817.

Eggers, Mitchell L., and Douglas S. Massey. 1992. “A Longitudinal Analysis of Urban Poverty: Blacks in U.S. Metropolitan Areas Between 1970 and 1980.” Social Science Research 21: $175-203$.

Engbersen, G. 1991. "Moderne Armoede: Feit En Fictie.” Sociologische Gids 37: 7-23.

Firebaugh, Glenn. 2000. "Empirics of World Income Inequality.” American Journal of Sociology 104: 1597-1630. 
Foster, James E. 1998. "What is Poverty and Who are the Poor? Redefinition for the United States in the 1990s: Absolute versus Relative Poverty." American Economic Review 88: $335-341$.

Friedman, Milton. 1982 [1962]. Capitalism and Freedom Chicago: The University of Chicago Press.

Gordon, David M. 1972. Theories of Poverty and Underemployment: Orthodox, Radical, and Dual Labor Market Perspectives Lexington, MA: Lexington Books.

Gore, Charles. 1995. “Chapter 1 Introduction: Markets, Citizenship and Social Exclusion.” Pp. 140 in Social Exclusion: Rhetoric Reality Responses, edited by Gerry Rodgers, Charles Gore, and Jose B. Figueiredo. Geneva: International Labour Organization.

Hagenaars, Aldi J.M. 1991. “The Definition and Measurement of Poverty.” Pp. 134-156 in Economic Inequality and Poverty: International Perspectives Armonk, NY: M.E. Sharpe.

Handcock, Mark S., and Martina Morris. 1998. "Relative Distribution Methods.” Sociological Methodology 28: 53-97.

Harrington, Michael. 1981 [1962]. The Other America NY: Penguin. 1984. The New American Poverty NY: Holt, Rinehart and Winston.

Harris, Kathleen Mullan. 1993. "Work and Welfare Among Single Mothers in Poverty." American Journal of Sociology 99: 317-352.

Haveman, Robert H. 1987. Poverty Policy and Poverty Research Madison, WI.: University of Wisconsin Press.

Jorgenson, Dale W. 1998. “Did We Lose the War on Poverty?” Journal of Economic Perspectives 12: 79-96. 
Kakwani, Nanak. 1993. "Statistical Inference in the Measurement of Poverty." The Review of Economics and Statistics 75: 632-639.

Katz, Michael B. 1989. The Undeserving Poor New York: Pantheon.

Kenworthy, Lane. 1999. "Do Social Welfare Policies Reduce Poverty? A Cross-National Assessment.” Social Forces 77: 1119-1140.

Korpi, Walter, and Joakim Palme. 1998. "The Paradox of Redistribution and Strategies of Equality: Welfare State Institutions, Inequality, and Poverty in the Western Countries.” American Sociological Review 63: 661-687.

Lichter, Daniel T. 1997. "Poverty and Inequality Among Children." Annual Review of Sociology 23: $121-145$.

Lichter, Daniel T. and David J. Eggebeen. 1993. "Rich Kids, Poor Kids: Changing Income Inequality Among American Children.” Social Forces 71: 761-780.

Madden, David. 2000. "Relative or Absolute Poverty Lines: A New Approach.” Review of Income and Wealth 46: 181-199.

Malakoff, David. 1998. “Famine Survivor Wins Economics Prize.” Science 282: 614a.

McLeod, Jane D. and Michael Shanahan. 1993. "Poverty, Parenting, and Children's Mental Health.” American Sociological Review 58: 351-366.

Moynihan, Daniel P. 1965. The Negro Family: The Case for National Action Washington, D.C.: Office of Planning and Research, U.S. Department of Labor.

Myles, John, and Garnett Picot. 2000. "Poverty Indices and Policy Analysis." Review of Income and Wealth 46: 161-179. 
Ormerod, Paul. 1998. "Unemployment and Social Exclusion: An Economic View." Pp. 23-40 in The Future of European Welfare, edited by M. Rhodes and Yves Meny. New York: St. Martin's Press.

Organisation for Economic Cooperation and Development. 1997. "Family, Market and Community: Equity and Efficiency in Social Policy.” Social Policy Studies No. 21. Paris, France: OECD.

Orshansky, Mollie. 1965. "Counting the Poor: Another Look at the Poverty Profile." Social Security Bulletin 28: 3-29.

Osberg, Lars, and Kuan Xu. 2000. “International Comparisons of Poverty Intensity: Index Decomposition and Bootstrap Inference.” The Journal of Human Resources 35: 51-81.

Paugam, Serge. 1998. "Poverty and Social Exclusion: A Sociological View." Pp. 41-62 in The Future of European Welfare, edited by M. Rhodes and Yves Meny. New York: St. Martin's Press.

President's Commission on Income Maintenance Programs. 1969. Poverty Amid Plenty Washington, D.C.: U.S. Govt. Printing Office.

Procacci, Giovanna. 1998. "Against Exclusion: The Poor and the Social Sciences.” Pp. 63-78 in The Future of European Welfare, edited by M. Rhodes and Yves Meny. New York: St. Martin's Press.

Quillian, Lincoln. 1999. "Migration Patterns and the Growth of High-Poverty Neighborhoods, 1970-1990." American Journal of Sociology 105: 1-37.

Rankin, Bruce H. and James M. Quane. 2000. "Neighborhood Poverty and the Social Isolation of Inner-City African-American Families.” Social Forces 79: 139-164. 
Ravallion, Martin 1998. "Poverty Lines in Theory and Practice." Living Standards Measurement Study Working Paper, Number 133. Washington, D.C.: The World Bank.

Rawls, John. 1971. A Theory of Justice Cambridge, MA.: Harvard University Press.

Rodgers, Gerry. 1995. “What is Special About a 'Social Exclusion’ Approach?” Pp. 43-55 in Social Exclusion: Rhetoric Reality Responses, edited by Gerry Rodgers, Charles Gore, and Jose B. Figueiredo. Geneva: International Labour Organization.

Ruggles, Patricia. 1990. Drawing the Line Washington, D.C.: The Urban Institute Press.

Schuyt, C. and A. Tan. 1998. "De Maatschappelijke Betekenis Van Armoede. Deel II", Op Zoek Naar Armoede En Bestaansonzekerheid Langs Twee Sporen, Nationale Raad Voor Maatschappelijk Welzijn, Rijswijk, pp. 34-54.

Sen, Amartya. 1999. Development as Freedom New York: Anchor Books. . 1992. Inequality Reexamined Cambridge, MA: Harvard University Press. . 1983. "Poor, Relatively Speaking." Oxford Economic Papers 35: 153-169. . 1979. "Issues in the Measurement of Poverty." Scandinavian Journal of Economics 81: 285-307 . 1976. "Poverty: An Ordinal Approach to Measurement." Econometrica 44: 219-231.

Sen, Pranab Kumar. 1986. “The Gini Coefficient and Poverty Indexes: Some Reconciliations.” Journal of the American Statistical Association 81: 1050-1057.

Shanahan, Suzanne Elise and Nancy Brandon Tuma. 1994. "The Sociology of Distribution and Redistribution.” Pp. 733-765 in The Handbook of Economic Sociology, edited by N.J. Smelser and R. Swedberg. Princeton, N.J.: Princeton University Press.

Shorrocks, Anthony F. 1995. "Revisiting the Sen Poverty Index." Econometrica 63: 1225-1230. 
Silver, Hilary. 1995. "Reconceptualizing Social Disadvantage: Three Paradigms of Social Exlclusion.” In Social Exclusion: Rhetoric, Reality, Responses, edited by G. Rodgers, C. Gore, and J.B. Figueiredo. Geneva: ILO. . 1994. "Social Exclusion and Social Solidarity: Three Paradigms." International Labour Review 133: 531-578.

Slesnick, Daniel T. 1993. "Gaining Ground: Poverty in the Postwar United States." Journal of Political Economy 101: 1-38.

Smeeding, Timothy M., Michael O’Higgins, and Lee Rainwater. 1990. Poverty, Inequality and Income Distribution in Comparative Perspective Washington, D.C.: The Urban Institute Press.

Smeeding, Timothy M., Lee Rainwater, Martin Rein, Richard Hauser, and Gaston Schaber. 1990. "Income Poverty in Seven Countries: Initial Estimates from the LIS Database." Pp. 57-76 in T.M. Smeeding, M. O’Higgins, and L. Rainwater (eds.), Poverty, Inequality and Income Distribution in Comparative Perspective Washington, D.C.: The Urban Institute Press.

Smeeding, Timothy M., Peter Saunders, John Coder, Stephen Jenkins, Johan Fritzell, Aldi J. M. Hagenaars, Richard Hauser, and Michael Wolfson. 1993. "Poverty, Inequality, and Family Living Standards Impacts Across Seven Nations: The Effect of Noncash Subsidies for Health, Education and Housing." Review of Income and Wealth 39: 229256.

Smith, Adam. 1937 [1776]. An Inquiry into the Nature and Causes of the Wealth of Nations New York: The Modern Library, Random House. 
South, Scott J., and Kyle D. Crowder. 1999. "Neighborhood Effects on Family Formation:

Concentrated Poverty and Beyond.” American Sociological Review 64: 113-132.

Sullivan, Teresa A., Elizabeth Warren, and Jay Lawrence Westbrook. 2000. The Fragile Middle Class: Americans in Debt New Haven: Yale University Press.

Takayama, Noriyuki. 1979. “Poverty, Income Inequality, and Their Measures: Professor Sen's Axiomatic Approach Reconsidered." Econometrica 47: 747-759.

Townsend, Peter. 1980. "Research on Poverty." Pp. 299-306 in Wealth, Income and Inequality, edited by A. B. Atkinson. NY: Oxford University Press. . 1962. "The Meaning of Poverty." British Journal of Sociology 13: 210-227.

Triest, Robert K. 1998. “Has Poverty Gotten Worse?” Journal of Economic Perspectives 12: 97114.

Uchitelle, Louis. 1999. "Devising New Math to Define Poverty: Millions More Would Be Poor in Fresher Census Formula." New York Times October 18: A1, A14.

Wacquant, Loic J.D. 1995. "The Comparative Structure and Experience of Urban Exclusion: 'Race,' Class, and Space in Chicago and Paris." Pp.543-570 in Poverty, Inequality and the Future of Social Policy: Western States in the New World Order, edited by K. McFate, R. Lawson, and W.J.Wilson. New York: Russell Sage Foundation.

Watts, Harold W. 1986. "Have Our Measures of Poverty Become Poorer?” Focus 9: 18-23. . 1968. "An Economic Definition of Poverty," in On Understanding Poverty, edited by D.P. Moynihan. NY, NY: Basic Books.

Weinberg, A. and J.C. Ruano-Borbalan. 1993. “Comprendre l'exclusion.' Sciences Humaines 28: $12-15$. 
Wilson, William Julius. 1987. The Truly Disadvantaged Chicago, IL: University of Chicago Press.

_. 1991. "Studying Inner-City Social Dislocations: The Challenge of Public Agenda Research." American Sociological Review. 56: 1-14.

Wu, Lawrence. 1996. "Effects of Family Instability, Income, and Income Instability on the Risk of Premarital Birth.” American Sociological Review 61: 386-406. 
Table 1. The Alternative Poverty Measures Emerging from The Ordinalist Revolution.

\begin{tabular}{|c|c|c|c|c|}
\hline & Symbol & Definition & Advantages & Disadvantages \\
\hline Headcount & $H$ & $\begin{array}{l}\% \text { of Population Below } \\
50 \% \text { of Median } \\
\text { Income }\end{array}$ & $\begin{array}{l}\text { Simple, dichotomous } \\
\text { measure of the } \% \text { of } \\
\text { the population } \\
\text { socially excluded }\end{array}$ & $\begin{array}{l}\text { Ignores the depth of } \\
\text { poverty among the } \\
\text { poor }\end{array}$ \\
\hline Income Gap & $I$ & $\begin{array}{l}\text { Difference between } \\
\text { population's median } \\
\text { income and mean } \\
\text { income of poor with } \boldsymbol{H} \text {, } \\
\text { standardized by } \\
\text { population's median } \\
\text { income }\end{array}$ & $\begin{array}{l}\text { Continuous variable } \\
\text { of the average depth } \\
\text { of poverty among the } \\
\text { poor }\end{array}$ & $\begin{array}{l}\text { Ignores the quantity } \\
\text { of poor people }\end{array}$ \\
\hline Interval & $H I$ & Product of $\boldsymbol{H} * \boldsymbol{I}$ & $\begin{array}{l}\text { Simple, parsimonious } \\
\text { measure combining } \\
\text { quantity and depth of } \\
\text { poverty }\end{array}$ & $\begin{array}{l}\text { Does not weight } \\
\text { index with the } \\
\text { distribution of } \\
\text { income of the poor }\end{array}$ \\
\hline Ordinal & $O$ & $\begin{array}{l}\boldsymbol{H I} *(1+\mathbf{C V}), \text { where } \\
\mathbf{C V} \text { is coefficient of } \\
\text { variation }\end{array}$ & $\begin{array}{l}\text { Weights measure so } \\
\text { the deeply poor have } \\
\text { more impact than } \\
\text { barely poor }\end{array}$ & $\begin{array}{l}\text { May add unimportant } \\
\text { information or } \\
\text { unneeded complexity }\end{array}$ \\
\hline $\begin{array}{l}\text { Sum of } \\
\text { Ordinals }\end{array}$ & SO & $\begin{array}{l}\text { Sum of } \boldsymbol{H} \text { 's for } 60 \% \text {, } \\
50 \%, 40 \%, 30 \%, 20 \% \text {, } \\
10 \% \text { and } 5 \% \text { of } \\
\text { Median Income }\end{array}$ & $\begin{array}{l}\text { Provides clear, } \\
\text { interpretable } \\
\text { graphical } \\
\text { representation }\end{array}$ & $\begin{array}{l}\text { Less precise } \\
\text { information about } \\
\text { distribution of poor } \\
\text { than } \boldsymbol{H I} \text { or } \boldsymbol{O}\end{array}$ \\
\hline
\end{tabular}


Table 2. The Criteria for Ideal Measures of Poverty.

1. Measure Comparative and Historical Variation Effectively

2. Be Relative Rather Than Absolute

3. Conceptualize Poverty as Social Exclusion

4. Assess the Impact of Taxes, Transfers, and State Benefits

5. Integrate the Depth of Poverty and the Inequality Among the Poor 
Table 3. Content Analysis of Empirical, Quantitative Sociological Research and the Measurement of Poverty between 1990-2001.

\begin{tabular}{|c|c|}
\hline & Frequency (Percentage of Total) \\
\hline Total Studies & 53 \\
\hline U.S. Official Measure & $37(69.81 \%)$ \\
\hline $\begin{array}{l}\text { Augmentation of U.S. Measure } \\
\text { (e.g. } 150 \%)\end{array}$ & $6(11.32 \%)$ \\
\hline Broader Scale Including U.S. Measure & $5(9.43 \%)$ \\
\hline Recipients of Assistance (e.g. AFDC) & $12(22.64 \%)$ \\
\hline $\begin{array}{l}\text { Deep or Severe Poverty } \\
\text { (e.g. } 40 \% \text { U.S. Threshold) }\end{array}$ & $4(7.55 \%)$ \\
\hline $\begin{array}{l}\text { Persistent or Long-Term Poverty } \\
\text { (e.g. Length of Time under U.S. Measure) }\end{array}$ & $8(15.09 \%)$ \\
\hline Low Income & $8(15.09 \%)$ \\
\hline $\begin{array}{l}\text { Relative Measure } \\
\text { (e.g. } 50 \% \text { of Median Income) }\end{array}$ & $5(9.43 \%)$ \\
\hline $\begin{array}{l}\text { Examine Comparative/ International } \\
\text { Variation in Poverty }\end{array}$ & $4(7.55 \%)$ \\
\hline Include Post-Tax or Transfer Measure & $5(9.43 \%)$ \\
\hline Measure Inequality Among Poor & $0(0.00 \%)$ \\
\hline
\end{tabular}


Table 4. Descriptive Statistics for Alternative Poverty Measures Based on Luxembourg Income Study Data, 1967-1997.

\begin{tabular}{|c|c|c|c|}
\hline & Mean & $\begin{array}{l}\text { Standard } \\
\text { Deviation } \\
\end{array}$ & $\begin{array}{l}\text { Coefficient of } \\
\text { Variation } \\
\end{array}$ \\
\hline \multicolumn{4}{|l|}{ Market Generated $(\mathrm{N}=72)$} \\
\hline Headcount $(\mathrm{H})$ & 31.743 & 4.387 & .138 \\
\hline Poverty Income Gap (I) & .879 & .048 & .054 \\
\hline Interval Poverty (HI) & 28.050 & 4.867 & .174 \\
\hline Inequality Among Poor (CV) & 1.360 & .544 & .400 \\
\hline Ordinal Poverty $(\mathrm{O})$ & 67.748 & 2.735 & .365 \\
\hline Sum of Ordinals (SO) & 181.469 & 35.890 & .198 \\
\hline \multicolumn{4}{|l|}{ State Mediated $(\mathbf{N}=73)$} \\
\hline Headcount $(\mathrm{H})$ & 9.711 & 3.846 & .396 \\
\hline Poverty Income Gap (I) & .681 & .065 & .095 \\
\hline Interval Poverty (HI) & 6.616 & 2.674 & .404 \\
\hline Inequality Among Poor (CV) & .478 & .202 & .422 \\
\hline Ordinal Poverty (O) & 9.818 & 4.133 & .421 \\
\hline Sum of Ordinals (SO) & 38.958 & 13.961 & .358 \\
\hline
\end{tabular}


Table 5. Patterns in Market Generated Poverty With Different Measures Across Sixteen Western Nations Circa 1995.

\begin{tabular}{|c|c|c|c|c|c|c|c|}
\hline Country & Year & $\begin{array}{l}\text { Headcount } \\
\text { (H) }\end{array}$ & $\begin{array}{c}\text { Poverty } \\
\text { Income Gap } \\
\text { (I) }\end{array}$ & $\begin{array}{c}\text { Interval } \\
\text { Poverty } \\
\text { (HI) }\end{array}$ & $\begin{array}{c}\text { Inequality } \\
\text { Among } \\
\text { Poor } \\
\text { (CV) }\end{array}$ & $\begin{array}{c}\text { Ordinal } \\
\text { Poverty } \\
(O)\end{array}$ & $\begin{array}{c}\text { Sum of } \\
\text { Ordinals } \\
\text { (SO) }\end{array}$ \\
\hline Australia & 1994 & $34.3(8)$ & $.919(3)$ & $31.508(8)$ & $1.505(5)$ & $78.934(5)$ & $205.4(7)$ \\
\hline Belgium & 1997 & $40.1(1)$ & $.947(1)$ & $37.984(1)$ & $2.167(1)$ & $120.296(1)$ & $257.3(1)$ \\
\hline Canada & 1994 & 29.9 (13) & $.842(14)$ & $25.174(14)$ & $1.025(12)$ & $50.973(14)$ & $157.7(14)$ \\
\hline Denmark & 1995 & $38.9(2)$ & $.903(7)$ & $35.109(2)$ & $1.420(6)$ & $84.954(3)$ & $230.3(2)$ \\
\hline Finland & 1995 & 30.1 (14) & $.811(16)$ & $24.405(15)$ & $.847(16)$ & $45.070(15)$ & $148.7(15)$ \\
\hline France & 1994 & $36.2(6)$ & $.895(8)$ & $32.404(5)$ & $1.301(8)$ & $74.577(6)$ & $212.6(5)$ \\
\hline Germany & 1994 & $36.2(6)$ & .917 (4) & $33.192(4)$ & $1.660(2)$ & $88.277(2)$ & $220.5(3)$ \\
\hline Italy & 1995 & 36.8 (4) & $.919(2)$ & $33.820(3)$ & $1.390(7)$ & $80.823(4)$ & $217.2(4)$ \\
\hline Luxembourg & 1994 & $29.1(15)$ & $.916(5)$ & $26.661(12)$ & $1.637(3)$ & $70.303(9)$ & $178.4(12)$ \\
\hline Netherlands & 1994 & $33.9(10)$ & $.879(10)$ & $29.805(9)$ & $1.163(10)$ & $64.458(10)$ & $190.4(9)$ \\
\hline Norway & 1995 & $34.3(8)$ & $.848(12)$ & $29.081(10)$ & $.981(13)$ & $57.603(12)$ & $181.9(11)$ \\
\hline Spain & 1990 & $31.3(11)$ & $.908(6)$ & $28.435(11)$ & $1.583(4)$ & $73.459(7)$ & $188.2(10)$ \\
\hline Sweden & 1995 & $37.9(3)$ & $.851(11)$ & $32.246(6)$ & .949 (14) & $62.851(11)$ & $199.3(8)$ \\
\hline Switzerland & 1992 & $24.2(16)$ & $.839(15)$ & $20.315(16)$ & $.918(15)$ & $38.959(16)$ & $123.9(16)$ \\
\hline U.K. & 1995 & $36.3(5)$ & $.882(9)$ & $32.024(7)$ & $1.248(9)$ & $71.989(8)$ & $209.4(6)$ \\
\hline U.S.A. & 1994 & $31.1(12)$ & $.846(13)$ & $26.302(13)$ & $1.053(11)$ & $53.995(13)$ & $165.6(13)$ \\
\hline $\begin{array}{l}\text { Index } \\
\text { Correlation } \\
\text { with } \mathrm{H} \\
(\mathrm{N}=72)\end{array}$ & & & .671 & .974 & .416 & .682 & .933 \\
\hline $\begin{array}{l}\text { Rank } \\
\text { Correlation } \\
\text { with } \mathrm{H} \\
(\mathrm{N}=16)\end{array}$ & & & .542 & .929 & .347 & .711 & .884 \\
\hline
\end{tabular}

Note: The numbers in parentheses are relative rankings, with 1 being the greatest amount of poverty with a particular measure and 16 being the least. 
Table 6. Patterns in State Mediated Poverty With Different Measures Across Sixteen Western Nations Circa 1995.

\begin{tabular}{|c|c|c|c|c|c|c|c|}
\hline Country & Year & $\begin{array}{l}\text { Headcount } \\
(H)\end{array}$ & $\begin{array}{c}\text { Poverty } \\
\text { Income Gap } \\
\text { (I) }\end{array}$ & $\begin{array}{c}\text { Interval } \\
\text { Poverty } \\
\text { (HI) }\end{array}$ & $\begin{array}{c}\text { Inequality } \\
\text { Among } \\
\text { Poor } \\
(\mathrm{CV})\end{array}$ & $\begin{array}{c}\text { Ordinal } \\
\text { Poverty } \\
(O)\end{array}$ & $\begin{array}{c}\text { Sum of } \\
\text { Ordinals } \\
\text { (SO) }\end{array}$ \\
\hline Australia & 1994 & $13.7(2)$ & $.745(5)$ & $10.210(2)$ & $.612(5)$ & $16.454(2)$ & $63.1(2)$ \\
\hline Belgium & 1997 & 7.7 (14) & $.652(11)$ & $5.020(14)$ & $.467(7)$ & 7.365 (13) & $30.3(13)$ \\
\hline Canada & 1994 & $11.1(4)$ & $.650(12)$ & $7.214(6)$ & $.327(15)$ & $9.572(9)$ & $39.6(7)$ \\
\hline Denmark & 1995 & $9.1(9)$ & $.776(3)$ & $7.063(8)$ & $.820(2)$ & $12.853(5)$ & $45.5(5)$ \\
\hline Finland & 1995 & $4.7(15)$ & $.638(14)$ & $3.000(15)$ & $.811(3)$ & $5.432(15)$ & $18.6(15)$ \\
\hline France & 1994 & $8.5(11)$ & $.623(15)$ & $5.300(12)$ & $.438(11)$ & 7.619 (12) & $30.4(12)$ \\
\hline Germany & 1994 & $7.8(13)$ & $.658(10)$ & $5.132(13)$ & $.383(13)$ & $7.100(14)$ & $30.0(14)$ \\
\hline Italy & 1995 & $13.3(3)$ & $.695(6)$ & $9.240(3)$ & $.451(8)$ & 13.405 (4) & $52.1(4)$ \\
\hline Luxembourg & 1994 & $3.5(16)$ & $.593(16)$ & $2.075(16)$ & $.230(16)$ & $2.553(16)$ & $16.1(16)$ \\
\hline Netherlands & 1994 & $8.7(10)$ & $.882(1)$ & $7.672(5)$ & $.647(4)$ & $12.638(5)$ & $39.2(9)$ \\
\hline Norway & 1995 & $8.5(11)$ & $.669(9)$ & $5.688(11)$ & $.447(10)$ & $8.229(10)$ & $34.7(11)$ \\
\hline Spain & 1990 & $9.4(7)$ & $.640(13)$ & $6.017(10)$ & $.345(14)$ & $8.092(11)$ & $35.3(10)$ \\
\hline Sweden & 1995 & $9.3(8)$ & $.748(4)$ & $6.956(9)$ & $.540(6)$ & $10.713(7)$ & $39.5(8)$ \\
\hline Switzerland & 1992 & $10.3(6)$ & $.787(2)$ & $8.110(4)$ & $.911(1)$ & $15.499(3)$ & $52.8(3)$ \\
\hline U.K. & 1995 & $10.6(5)$ & $.674(8)$ & $7.143(7)$ & .449 (9) & $10.348(8)$ & $42.1(6)$ \\
\hline U.S.A. & 1994 & $18.2(1)$ & $.680(7)$ & $12.368(1)$ & $.418(12)$ & 17.538 & $67.5(1)$ \\
\hline $\begin{array}{l}\text { Correlation } \\
\text { with } \mathrm{H} \\
(\mathrm{N}=73)\end{array}$ & & & .018 & .980 & -.082 & .889 & .954 \\
\hline $\begin{array}{l}\text { Rank } \\
\text { Correlation } \\
\text { with } \mathrm{H} \\
(\mathrm{N}=16)\end{array}$ & & & .479 & .927 & .037. & .844 & .927 \\
\hline
\end{tabular}

Note: The numbers in parentheses are relative rankings, with 1 being the greatest amount of poverty with a particular measure and 16 being the least. 
Table 7. Trends in U.S. Poverty With Official U.S. Measure, Interval, Ordinal and Sum of Ordinals Measures, 1974-1997.

\begin{tabular}{|c|c|c|c|c|c|}
\hline Year & Official U.S. & $\begin{array}{l}\text { MG Interval } \\
(M G I)\end{array}$ & $\begin{array}{l}\text { SM Interval } \\
\text { (SM I) }\end{array}$ & $\begin{array}{l}\text { SM Ordinal } \\
(S M O)\end{array}$ & $\begin{array}{l}\text { SM Sum of } \\
\text { Ordinals } \\
\text { (SM SO) }\end{array}$ \\
\hline 1974 & $11.2(6)$ & $23.756(6)$ & $11.665(5)$ & $16.821(5)$ & $63.8(5)$ \\
\hline$\%$ Change & +4.464 & +.960 & -1.312 & -2.848 & -1.724 \\
\hline 1979 & $11.7(5)$ & $23.984(5)$ & $11.512(6)$ & $16.342(6)$ & $62.7(6)$ \\
\hline$\%$ Change & +19.658 & +2.769 & +9.147 & +6.902 & +6.858 \\
\hline 1986 & $14.0(3)$ & $24.800(4)$ & $12.565(1)$ & $17.470(2)$ & $67.0(2)$ \\
\hline$\%$ Change & +1.429 & +2.677 & -3.191 & -2.536 & -1.642 \\
\hline 1991 & $14.2(2)$ & $25.464(2)$ & $12.164(3)$ & $17.027(4)$ & $65.9(4)$ \\
\hline$\%$ Change & +2.113 & +3.291 & +1.677 & +3.001 & +2.428 \\
\hline 1994 & $14.5(1)$ & $26.302(1)$ & $12.368(2)$ & $17.538(1)$ & $67.5(1)$ \\
\hline$\%$ Change & -8.276 & -3.608 & -3.064 & -2.623 & -2.074 \\
\hline 1997 & $13.3(4)$ & $25.353(3)$ & $11.989(4)$ & $17.078(3)$ & $66.1(3)$ \\
\hline $\begin{array}{l}\text { 1974-1997 } \\
\text { \% Change }\end{array}$ & +18.750 & +6.723 & +2.778 & +1.528 & +3.605 \\
\hline
\end{tabular}

Note: The numbers in parentheses are relative rankings, with 1 being the greatest amount of poverty with a particular measure and 6 being the least. \% Change is the rate of change between the previous and following years, defined as: $\left(\left(\mathrm{X}_{\mathrm{t} 2}-\mathrm{X}_{\mathrm{t} 1}\right) / \mathrm{X}_{\mathrm{t} 1}\right) * 100$. 
Table 8. Results of Market Generated and State Mediated Interval Poverty in Western Countries 1969-1997.

\begin{tabular}{|c|c|c|c|c|c|c|c|}
\hline Country & Year & MG Interval & SM Interval & $\begin{array}{l}\text { MG Sum of } \\
\text { Ordinals }\end{array}$ & $\begin{array}{l}\text { SM Sum of } \\
\text { Ordinals }\end{array}$ & MG Ordinal & SM Ordinal \\
\hline Australia & 1981 & 25.285 & 7.844 & 165.3 & 47.0 & 58.171 & 11.002 \\
\hline Australia & 1985 & 27.660 & 8.006 & 181.0 & 48.0 & 63.778 & 11.108 \\
\hline Australia & 1989 & 26.538 & 8.084 & 172.2 & 47.6 & 59.437 & 11.216 \\
\hline Austria & 1987 & -- & 4.085 & -- & 21.8 & -- & 4.945 \\
\hline Austria & 1995 & -- & 7.833 & -- & 47.3 & -- & 12.498 \\
\hline Belgium & 1985 & 33.020 & 3.350 & 227.3 & 20.7 & 146.120 & 4.807 \\
\hline Belgium & 1988 & 33.886 & 3.568 & 232.8 & 23.4 & 130.562 & 5.506 \\
\hline Belgium & 1992 & 36.189 & 3.973 & 250.6 & 27.5 & 154.035 & 6.578 \\
\hline Canada & 1971 & 25.090 & 15.101 & 159.8 & 84.8 & 55.945 & 23.728 \\
\hline Canada & 1975 & 22.737 & 12.165 & 142.4 & 66.2 & 46.160 & 17.800 \\
\hline Canada & 1981 & 21.007 & 9.474 & 130.7 & 52.5 & 41.132 & 13.299 \\
\hline Canada & 1987 & 21.818 & 7.662 & 134.1 & 42.5 & 41.548 & 10.241 \\
\hline Canada & 1991 & 23.547 & 7.816 & 145.4 & 43.7 & 45.949 & 10.771 \\
\hline Canada & 1997 & 24.643 & 7.860 & 154.9 & 44.2 & 50.152 & 12.260 \\
\hline Denmark & 1987 & 32.106 & 6.919 & 206.6 & 43.7 & 73.487 & 11.072 \\
\hline Denmark & 1992 & 34.051 & 5.738 & 219.8 & 35.5 & 78.970 & 9.334 \\
\hline Denmark & 1997 & 35.016 & 6.641 & 230.1 & 42.8 & 84.414 & 11.400 \\
\hline Finland & 1987 & 18.236 & 4.006 & 106.0 & 23.7 & 29.810 & 5.126 \\
\hline Finland & 1991 & 17.152 & 4.317 & 99.9 & 25.7 & 27.839 & 5.921 \\
\hline France & 1979 & 27.455 & 6.146 & 178.9 & 35.5 & 66.425 & 11.967 \\
\hline France & 1981 & 13.272 & 5.972 & 80.8 & 35.3 & 23.252 & 8.269 \\
\hline France & 1984 & 28.603 & 5.199 & 186.9 & 32.8 & 69.212 & 7.967 \\
\hline France & 1989 & 32.191 & 7.288 & 218.7 & 44.0 & 98.449 & 14.257 \\
\hline Germany & 1973 & 27.040 & 6.215 & 172.4 & 35.7 & 57.176 & 9.751 \\
\hline Germany & 1978 & 31.287 & 5.517 & 198.9 & 31.0 & 66.308 & 7.997 \\
\hline Germany & 1981 & 32.095 & 4.225 & 219.0 & 25.7 & 107.797 & 5.460 \\
\hline Germany & 1983 & 28.975 & 3.925 & 181.3 & 23.4 & 56.538 & 4.800 \\
\hline Germany & 1984 & 32.486 & 4.267 & 221.0 & 24.4 & 92.360 & 5.222 \\
\hline Germany & 1989 & 29.473 & 4.126 & 198.3 & 24.9 & 78.668 & 5.655 \\
\hline Ireland & 1987 & 32.357 & 5.938 & 208.8 & 36.5 & 80.231 & 9.147 \\
\hline Italy & 1986 & 29.590 & 6.564 & 198.1 & 35.9 & 79.378 & 8.331 \\
\hline Italy & 1991 & 27.955 & 6.049 & 187.1 & 35.9 & 68.276 & 8.059 \\
\hline Luxembourg & 1985 & 28.228 & 3.310 & 193.9 & 20.9 & 103.096 & 4.384 \\
\hline Luxembourg & 1991 & 25.204 & 2.167 & 165.1 & 17.3 & 61.149 & 2.566 \\
\hline Netherlands & 1983 & 31.454 & 5.877 & 209.8 & 38.7 & 87.371 & 12.806 \\
\hline Netherlands & 1987 & 31.608 & 5.108 & 212.5 & 33.3 & 89.523 & 10.479 \\
\hline Netherlands & 1991 & 28.119 & 5.149 & 180.9 & 32.4 & 60.685 & 8.588 \\
\hline Norway & 1979 & 28.811 & 4.237 & 184.7 & 31.2 & 64.275 & 6.479 \\
\hline Norway & 1986 & 26.338 & 5.258 & 169.4 & 32.7 & 56.061 & 7.154 \\
\hline Norway & 1991 & 26.185 & 4.540 & 164.8 & 30.0 & 51.270 & 6.758 \\
\hline Spain & 1980 & 26.240 & 7.893 & 173.9 & 44.5 & 68.528 & 10.537 \\
\hline Sweden & 1967 & 30.681 & 7.740 & 208.6 & 47.2 & 90.429 & 12.004 \\
\hline Sweden & 1975 & 29.675 & 5.016 & 191.7 & 33.6 & 67.419 & 7.591 \\
\hline Sweden & 1981 & 31.335 & 4.069 & 196.8 & 23.9 & 63.954 & 6.030 \\
\hline Sweden & 1987 & 31.525 & 6.846 & 198.9 & 38.1 & 63.460 & 10.278 \\
\hline Sweden & 1992 & 34.540 & 6.214 & 217.9 & 34.6 & 71.462 & 9.124 \\
\hline Switzerland & 1982 & 21.447 & 7.127 & 130.6 & 40.9 & 39.402 & 9.788 \\
\hline UK & 1969 & 20.265 & 4.152 & 132.2 & 26.9 & 44.802 & 5.026 \\
\hline UK & 1974 & 21.595 & 6.221 & 130.1 & 33.3 & 37.738 & 7.389 \\
\hline UK & 1979 & 29.295 & 5.024 & 194.2 & 32.6 & 71.776 & 6.645 \\
\hline UK & 1986 & 32.819 & 5.085 & 212.9 & 33.2 & 77.435 & 8.512 \\
\hline UK & 1991 & 30.612 & 8.207 & 198.2 & 46.7 & 68.816 & 10.763 \\
\hline USA & 1969 & 21.030 & -- & 131.1 & -- & 40.893 & -- \\
\hline USA & 1974 & 23.756 & 11.665 & 148.5 & 63.8 & 48.626 & 16.821 \\
\hline USA & 1979 & 23.984 & 11.512 & 149.8 & 62.7 & 47.979 & 16.342 \\
\hline USA & 1986 & 24.800 & 12.565 & 155.4 & 67.0 & 50.146 & 17.470 \\
\hline USA & 1991 & 25.464 & 12.164 & 159.2 & 65.9 & 50.916 & 17.027 \\
\hline USA & 1997 & 25.353 & 11.989 & 158.8 & 66.1 & 51.522 & 17.078 \\
\hline
\end{tabular}

Note: Cases were excluded from this table that were included in Tables 5 or 6. 


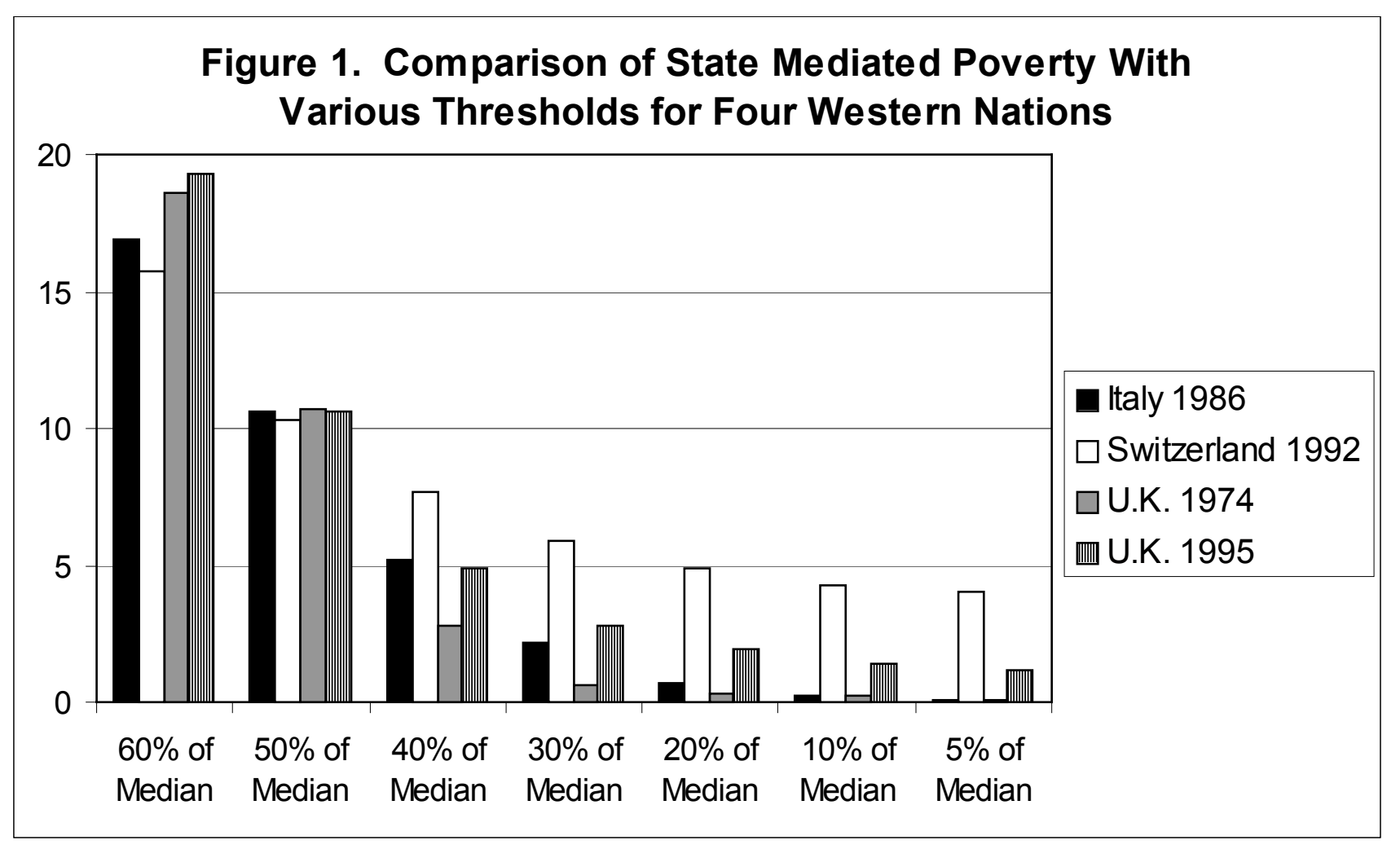



${ }^{1}$ In fact, Amartya Sen received a Nobel Prize in Economics in 1998 for work that included his revolutionary “Ordinal Approach” to measuring poverty (Malakoff 1998).

${ }^{2}$ The panel wrote, "The current poverty measure has weaknesses both in the implementation of the threshold concept and in the definition of family resources. Changing social and economic conditions over the last three decades have made these weaknesses more obvious and more consequential. As a result, the current measure does not accurately reflect differences in poverty across population groups and across time. We conclude that it would be inadvisable to retain the current measure for the future" (Citro and Michael 1995: xvi)

3 Orshansky used the Department of Agriculture's (DOA) "low cost food budget" and multiplied the dollar amount by three, assuming food amounted to one-third of a family's expenses. Importantly, Orshansky developed the line as a research tool, never intended it as a policy instrument and quickly repudiated it. Contrary to her intentions, Johnson's Office of Economic Opportunity adopted it, and utilized the DOA's "economy food plan" which was about 25 percent below the low-cost plan. Over time, the measure was further modified to become even more conservative and to sever the food-income link (Katz 1989: 115-117).

${ }^{4}$ As Watts (1986: 52) observes, “Our (official) measures are not grounded in some self-evident principle or expert consensus but are simply a collection of more or less arbitrary and eminently vulnerable rules. Their most remarkable feature is their widespread and persistent acceptance by the public and by those who make and criticize public policies."

${ }^{5}$ For example, food no longer amounts to one-third of a family's budget, and more accurately is about one-sixth. Ruggles (1990) also notes that inflationary adjustments are based on the cost of a basket of goods for the entire U.S. population (or at least all urban consumers) - which may not 
represent price changes for poor families and underestimates changes in rising standards of living.

${ }^{6}$ Hill and Michael (2001: 743) write, "If one expects poverty status to be negatively associated with school grades, math achievement, and expectations of completing college and avoiding pregnancy, and to be positively associated with school suspension, then the NRC poverty measure yields a larger estimate of those associations." Notably, the Census Bureau is currently experimenting with new measures in response to the NRC's recommendations. With one of these experimental measures, the threshold for a family of four in 1999 would have risen from $\$ 16,600$ to $\$ 19,500$. As a result, the poverty rate would have risen from $12.7 \%$ to about $17 \%$ in the U.S. (Uchitelle 1999).

${ }^{7}$ While the argument is not new (see Friedman 1982), several scholars provide evidence of a historical decline in poverty measured as absolute consumption, and contend that the U.S. poor are more affluent than the middle class in previous decades (Cox and Alm 1999; Jorgenson 1998; Slesnick 1993). Though methodological limitations should be noted (see Hagenaars 1991; Kakwani 1993; Triest 1998; Lichter 1997), the greatest concern with this approach is that it conceptualizes and measures poverty absolutely and divorced from cultural and historical context.

${ }^{8}$ Harrington $(1981: 18,187)$ emphasized, "What shall we tell the American poor, once we have seen them? Shall we say to them that they are better off than the Indian poor, the Italian poor, the Russian poor?. . .In the nineteenth century, conservatives in England used to argue against reform on the grounds that the British worker of the time had a longer life expectancy than a medieval nobleman. This is to say that a definition of poverty is, to a considerable extent, a historically conditioned matter. Indeed, if one wanted to play with figures, it would be possible 
to prove that there are no poor people in the United States, or at least only a few whose plight is as desperate as that of the masses in Hong Kong. There is starvation in American society, but it is not a pervasive social problem as it is in some the newly independent nations. There are still Americans who literally die in the streets, but their numbers are comparatively small."

${ }^{9}$ Townsend (1962: 219, 225) elaborates, "Poverty is a dynamic, not a static concept. Man is not a Robinson Crusoe living on a desert island. He is a social animal entangled in a web of relationships at work and in family and community which exert complex and changing pressures to which he must respond, as much in his consumption of goods and services as in any other aspect of this behavior. . .Our general theory, then, should be that individuals and families whose resources over time fall seriously short of the resources commanded by the average individual or family in the community in which they live,. . .are in poverty."

${ }^{10}$ Lichter (1997: 130) explains that, “Absolute increases in child poverty are arguably less important than several other relative dimensions of the current poverty problem. . Today's poverty among children must be judged against the living conditions and consumption levels of society as a whole and other advantaged groups - current and past. It is with regard to this relative dimension that implies increasing social and cultural differentiation in the future as the current generation of poor children enters adulthood."

${ }^{11}$ Notions of capability emerge from Rawls' (1971) political philosophy. Many scholars follow his prioritization of basic liberties in defining capability, social exclusion, and hence poverty (Atkinson 1987; 1998b). Despite his influence on poverty and inequality debates (see Sen 1992), Rawls (1971) made very few overt references to poverty. Atkinson (1987: 760) notes that the word "poverty" does not even appear in Rawls' extensive index. 
${ }^{12}$ Cantillion (1997: 131) suggests, "There is probably not a single characteristic that the 'socially excluded' have in common, except perhaps, not having a stable well-paying job." Atkinson (1998b: 20) exemplifies social exclusion as lacking a telephone in the home arguing, "A person unable to afford a telephone finds it difficult to participate in a society where the majority have telephones." While owning a telephone or lacking a job clearly reflects a person's market standing, these simple conditions also suggest complex social processes of dislocation and marginalization.

${ }^{13}$ Sen (1992: 115) explains further, "In a country that is generally rich, more income may be needed to buy enough commodities to achieve the same social functioning, such as 'appearing in public without shame.' The same applies to the capability of 'taking part in the life of the community.' These general social functionings impose commodity requirements that vary with what others in the community standardly have."

${ }^{14}$ For example, to investigate the direct impact of the market, poverty before taxes and transfers is preferable. If one is interested in the direct impact of the welfare state, poverty after taxes and transfers is preferable.

${ }^{15}$ For example, societies $\mathrm{A}$ and $\mathrm{B}$, with equal rates of poverty with $\mathbf{H}$, would be considered equivalent. However, while the poor in A may cluster close to the threshold, the poor in B may cluster close to zero income. H would be unable to detect this difference in depth and income distribution. Further, if the income distributions in A and B were identical at one point in time, H would be unable to detect if the poor in A suffered severe income loss and fell to zero income, while the poor in B were unchanged.

${ }^{16}$ One advantage of $\mathbf{H I}$ over $\mathbf{H}$ manifests in economic recessions. A relative $\mathbf{H}$ may be criticized because during a recession the median may decline, and households with stable income will 
suddenly be considered poor and will count equally as a household with no income. While the household would still be poor with $\mathbf{H I}$, since $\mathbf{H}$ is a component, the $\mathbf{I}$ component would decline, and the overall effect on $\mathbf{H I}$ would be less significant than with $\mathbf{H}$.

${ }^{17}$ In $\mathbf{O}, \mathrm{CV}$ is conventionally measured with the Gini index. However, research on inequality demonstrates that the Gini index can be replaced with the simpler Coefficient of Variation (CV), which is substantively identical and easier to compute (Allison 1978; Firebaugh 2000).

${ }^{18}$ One criticism of these more sophisticated measures raised by scholars unaware of this debates, is that one is basically measuring inequality. While poverty is a component of patterns at the bottom of the income distribution, a close empirical examination finds important differences between inequality and these poverty measures. In analyses with the LIS data, I found that the Gini coefficient of inequality has a correlation of about .7 with either $\mathbf{H}, \mathbf{H I}, \mathbf{O}$, or SO. These empirical results are available from the author upon request. Osberg and $\mathrm{Xu}$ (2000: 68) stress that, "Although there is a positive correlation between income inequality and poverty intensity, the relationship is far from perfect." Given that inequality and poverty indices measure different phenomena, poverty and inequality are better understood as complementary but theoretically distinct concepts and measures.

19 These criticisms apply mainly to U.S. sociology. Often, prominent European sociological journals include articles with more rigorous measures of poverty (see Bradshaw 2000).

${ }^{20}$ At a maximum, the U.S., Canada and Germany contribute seven cases, and at a minimum, Ireland contributes one, while Austria, Denmark, Spain and Switzerland contribute two. For Austria in 1987 and 1995, data on income before taxes and transfers (MG) was unavailable. For the U.S. in 1969, data on income after taxes and transfers (SM) was unavailable. Given the unavailability of these cases, my sample is 72 for MG and 73 for SM poverty. 
${ }^{21}$ Actually, this author is not aware of cross-national data on wealth or consumption that even approaches the extensiveness or standardization of LIS. As the NRC suggested, however, relative measures like these could easily be applied to wealth or consumption in the event that such data became available (Citro and Michael 1995).

${ }^{22} \mathrm{MG}$ income sums the variables: gross wages and salaries (V1), farm self-employment income (V4), non-farm self-employment income (V5), private pensions (V32), other regular private income (V34) and other cash income (V35). For Spain, all Market Generated estimates are based on income after taxes but before transfers. I have replicated all analyses with Spain excluded and the results are almost identical.

23 On rare occasions, cases will have negative values of income in the LIS - largely due to losses in self-employment. I have coded these cases as zero income to minimize any disproportionate bias on the Interval and Ordinal measures of poverty. In a few of the earlier data sets, the LIS is unable to determine if zero values for income variables are due to missing data or actual zero values. As a result, some analysts simply drop these cases from the sample and I have done so for Sweden (1967) and Switzerland (1982). With all other cases, I chose to keep these cases in the sample and allow zero values for income to be a possibility. Both the negative and zero values represent a very small (maybe negligible) proportion of any sample within the LIS. While my strategy for zero values may very modestly overestimate the quantity and depth of poverty, this seems preferable to the common problem of poverty measures that underestimate poverty. ${ }^{24}$ Command files for statistical packages (e.g. SPSS, STATA) to calculate these measures of poverty are available on the LIS website and from the author upon request. Also, data on the median U.S. household income is available on the U.S. Census department web page 
(www.census.gov). Analysts can estimate thresholds (e.g. 50\% of median) and average poverty gaps with this data and apply these thresholds to other data sets.

${ }^{25}$ One interesting possibility would be for analysts to construct poverty measures contextualized by regional, state or metropolitan area. Since poverty is relative and costs of living and median incomes vary across the U.S. significantly, a single national poverty rate may obscure the internally heterogeneity of nations as large and diverse as the U.S. In fact, multiple local relative poverty indices would be easily to compute out of the census and might be useful for examining spatially varying outcomes like racial inequality, crime rates, and infant and adult mortality. 